\title{
Comparative ecology of conifer-feeding spruce budworms (Lepidoptera: Tortricidae)
}

\author{
V.G. Nealis ${ }^{1}$
}

\begin{abstract}
The comparative ecology of conifer-feeding budworms in the genus Choristoneura Lederer (Lepidoptera: Tortricidae) in Canada is reviewed with emphasis on publications since 1980. Systematics and life history are updated and historical outbreak patterns and their current interpretation summarised. Recent evidence is analysed in the context of ecological interactions among three trophic levels; host plant, budworm herbivore, and natural enemies. The influence of weather and climate are viewed as modulating factors. The population behaviour of budworms is interpreted as the result of tri-trophic interactions that vary at different scales. The result of these multi-scale interactions is that despite shared phylogenetic constraints and common adaptations, different budworm species display different population behaviour because of specific ecological relationships with their respective hosts and natural enemies.
\end{abstract}

\section{Introduction}

When outbreaks of the spruce budworm (Choristoneura fumiferana (Clemens) (Lepidoptera: Tortricidae) came to the attention of Canadian foresters in the mid-20th century, entomologists already recognised the distinct forms of budworms living on different conifer tree species in different forest regions of North America. They also knew that spruce budworm outbreaks had damaged Canadian forests several times in the past (Craighead 1924; Mathers 1932; Turner 1952; Blais 1954). What was new by mid-century was that both forests and the industry they supported were changing rapidly and disturbances such as the spruce budworm were seen as a significant threat. Most jurisdictions in Canada had legislation that enabled active forest management and by the 1950s aerial application of pesticides to protect forests from spruce budworm became routine (Webb et al. 1961).

Since then, there has rarely been a year in living memory without significant forest damage caused by a budworm outbreak somewhere in Canada (Fig. 1). The basic research that accompanied the forest management response to these outbreaks has resulted in a forest-insect system for which knowledge and alternative interpretations are uncommonly rich. Much of this knowledge has been gained by scientists working in Canada. The concentration of expertise in a few government agencies and universities working on a mostly publically owned natural resource resulted in continuous effort that sustained both extensive annual surveys as well as investigation of the fundamental biology and ecology of these insects.

This paper compares the ecology of the major conifer-feeding species in the genus Choristoneura Lederer (Lepidoptera: Tortricidae) in Canada. These closely-related species share phylogenetic constraints which characterise their common evolutionary histories, and related adaptive syndromes which mitigate the fitness consequences of these constraints (Price 1994). The ecological relationships that emerge from these adaptations determine macro-ecological phenomena such as eruptive population cycles. I begin with a review of budworm systematics, life history, and seasonality followed by the evidence on historic outbreaks. These are the foundational elements and resulting patterns of population ecology. Next, I examine trophic interactions with a focus on new knowledge compiled in the past 30 years, coincidentally the duration of a typical research career. Trophic interactions are interpreted as ecological drivers that

Received 5 November 2014. Accepted 14 January 2015. First published online 29 May 2015.

V.G. Nealis, ${ }^{1}$ Natural Resources Canada-Canadian Forest Service, Pacific Forestry Centre, 506 W. Burnside Rd., Victoria, British Columbia, Canada V8Z 1M5

${ }^{1}$ Corresponding author (e-mail: Vince.Nealis@NRCan-RNCan.gc.ca).

Langor, D.W. and Alfaro, R.I. (eds.) Forest Entomology in Canada: Celebrating a Century of Science Excellence doi: $10.4039 /$ tce. 2015.15 
Fig. 1. Area of defoliation (millions of ha) by (A) spruce budworm in eastern Canada (Newfoundland and Labrador, New Brunswick, Nova Scotia, Prince Edward Island, Québec, Ontario), (B) spruce budworm, two-year cycle spruce budworm, and western spruce budworm in western Canada (Manitoba, Saskatchewan, Alberta, British Columbia, Yukon, Northwest Territories), and (C) jack pine budworm in Manitoba (MB), Saskatchewan (SK), Ontario (ON), and Québec (QC). (Source: National Forestry Database. http://nfdp.ccfm.org/insects/ quick_facts_e.php accessed 23 September 2014).
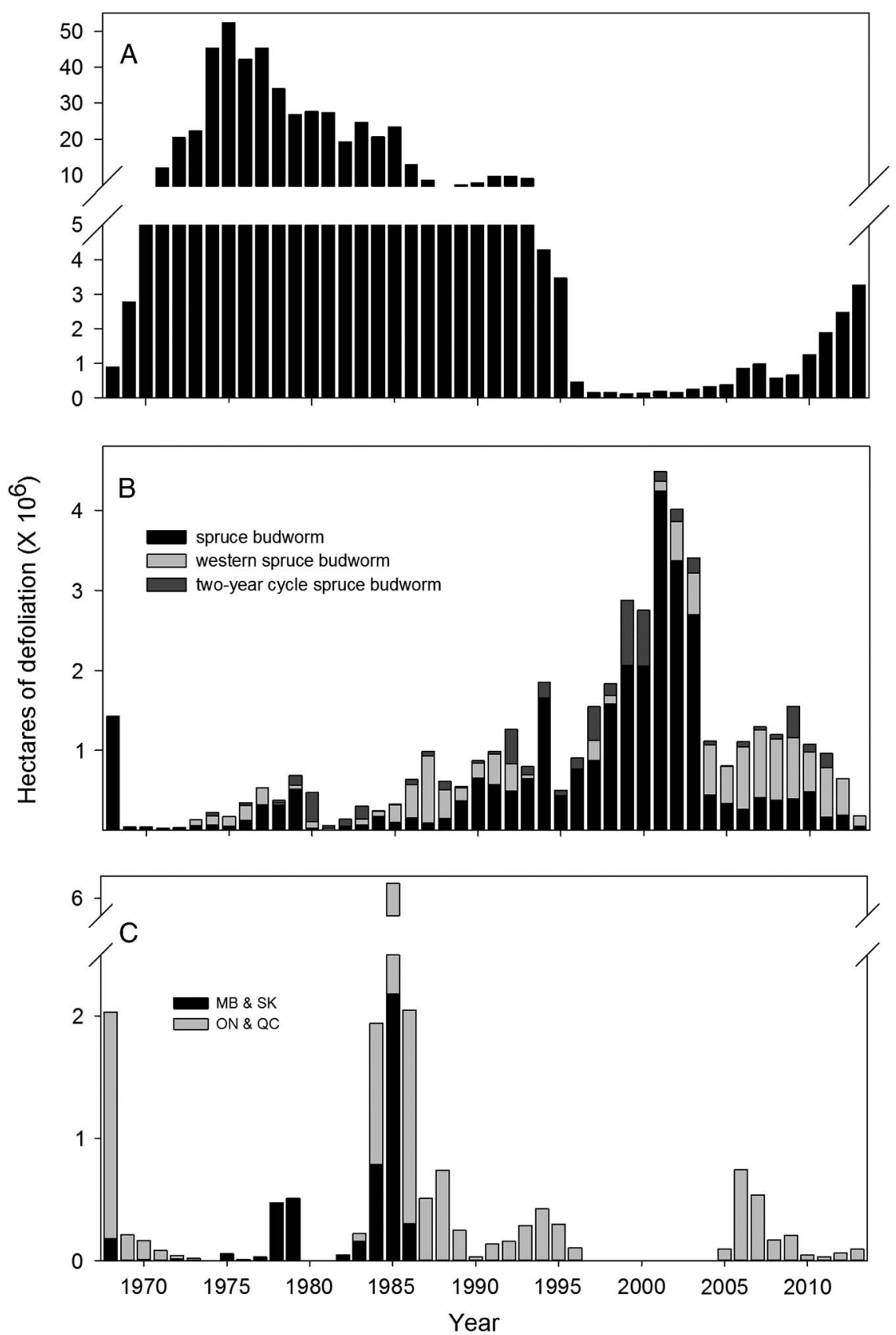
transcribe the consequences of adaptation in a variable environment to patterns of abundance in space and time.

The primary literature on the spruce budworm, C. fumiferana, alone is formidable. Including publications on other conifer-feeding budworm species makes parsimonious selection of citations a challenge. In keeping with the theme of this special issue, I have favoured publications by Canadian scientists where appropriate although given the volume of these the choices were not reduced by much. Excellent reviews became available following the last outbreak (Harvey 1985; Volney 1989; Sanders 1991) so I also have tried to restrict myself to post-1980 publications except what I consider to be original, seminal contributions that provide the enduring ideas and evidence that have influenced my view of budworm ecology.

\section{Conifer-feeding spruce budworms}

\section{Systematics}

So who are these budworms? Biosystematic analysis supports eight species in the spruce budworm complex of conifer-feeding Choristoneura in North America including six species in Canada (Lumley and Sperling 2010). Many more biotypes are recognised (Volney and Fleming 2007) and so more cryptic species may be revealed eventually (Lumley and Sperling 2011). Populations of four species: (eastern) spruce budworm; jack pine budworm, $C$. pinus pinus Freeman; western spruce budworm, C. occidentalis Freeman; and two-year cycle spruce budworm, $C$. biennis Freeman; have erupted extensively at least once during the last 50 years, a period representing barely one generation of tree and forest (Fig. 1). Collectively these species occupy most of Canada's major conifer forest ecozones (Fig. 2). The distribution and status in Canada of the coastal spruce budworm, C. orae Freeman, and a western pine-feeding budworm, C. lambertiana (Busck), are poorly known and not considered further.

The near identical life histories of these budworm species suggest close phylogenetic relationships and recent divergence. Until the 1950s, forest entomologists applied the species name "fumiferana" to all budworms even though they recognised different biogeographic entities associated with different host-tree species. The outbreaks that occurred in the mid-20th century prompted taxonomic revision of the group drawn from detailed morphological studies of adults (Freeman 1947) and larvae (MacKay 1962). The many polymorphisms within species and overlap of characters among species, however, obscured clear separation of species based on conventional morphology (Harvey 1985, 1996). Further, successful hybridisation between most species combinations and their progeny demonstrated high genetic compatibility within the genus (Volney 1989; Harvey 1997; Nealis 2005). Nonetheless, Freeman (1967) recognised the distinct species mentioned above among the different forms while the search continued for diagnostic morphological characters (Dang 1985) and biochemical attributes such as pheromones (Silk and Kuenen 1988), isozymes (Harvey 1985), and mitochondrial DNA (Sperling and Hickey 1995).

Despite this dedicated search for clear distinctions, effective separation of species requires information on morphology, geography, ecology, and genetics (Lumley and Sperling 2010). As noted by Stehr (1967), the simplest, most reliable method for distinguishing budworm species in Canada remains the geographic location and host-tree associations on which the population in question is found. This practical method of identification may become less reliable in western Canada as changing climate and forest composition create new areas of sympatry and potential hybridisation (Volney and Fleming 2007). Nonetheless, this biogeographical pattern and ecological relationship with the host-tree forms the reference point for this comparative review of their ecology. For brevity, I refer to "budworms" when describing attributes common to all species and either the scientific or accepted common name when making species distinctions.

\section{Life history}

Conifer-feeding budworms are relatively specialised, feeding on one or at most a few genera of tree species within a single plant family (Pinaceae). Each life stage is intimately associated with their preferred host species (Table 1). Adult moths mate soon after eclosion in mid-summer to late-summer and lay eggs on needles in imbricated masses ranging from 20 or fewer eggs per 
Fig. 2. Geographic distribution of major conifer-feeding budworms in the genus Choristoneura in North America (after Harvey 1985, courtesy of R Alfaro).

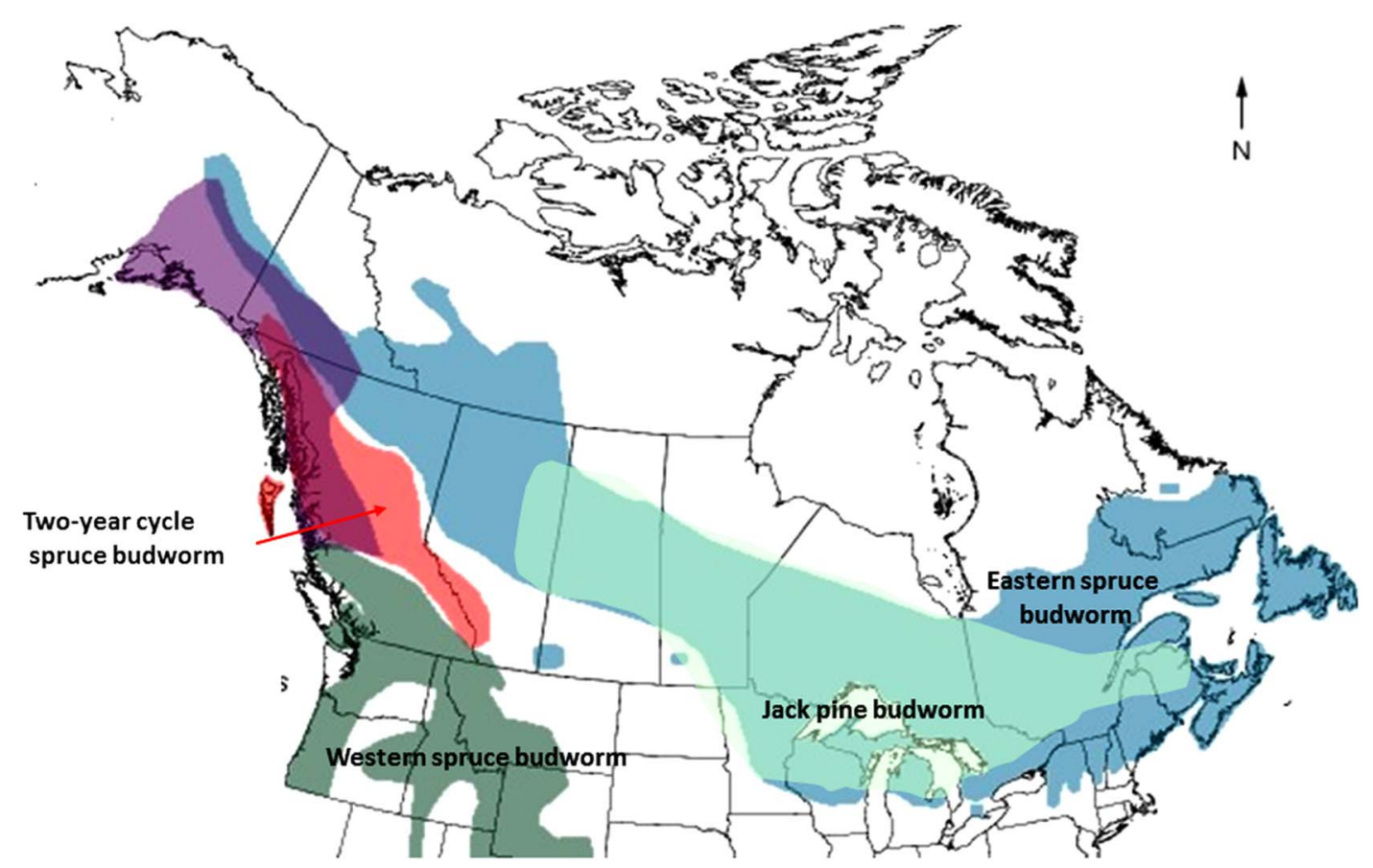

mass in the spruce budworm (Nealis and Régnière 2004a) to 60 eggs per mass in the jack pine budworm (Fowler and Simmons 1987) with the other species intermediate. Foliage architecture affects female oviposition behaviour (Grant 2006) and so the number of eggs per mass characteristic of a budworm species may be related to needle length of its preferred host (balsam fir and spruces have the shortest, and jack pine the longest, needle lengths in the spectrum). Lifetime fecundity for female spruce budworms can vary nearly threefold (80-220 eggs) depending on the quality and quantity of food (Nealis and Régnière 2004a). A similar range in lifetime fecundity has been estimated for western spruce budworm (personal observation) and available estimates of mean fecundity for jack pine budworm ( $\approx 130$ eggs) are comparable (Nealis 1995).

Hatch occurs in one to two weeks. Neonate larvae do not feed but disperse immediately in search of sheltered niches on the host tree where they spin an individual hibernaculum, moult, and pass late summer, autumn, and winter as a secondstage larva. Diapause terminates gradually in late winter after which budworms remain dormant until warmer spring conditions prevail (Régnière 1990; Nealis and Régnière 2014). Emergence of second-instar budworm from their hibernacula in the spring occurs in advance of bud-flush, at least in univoltine individuals, so that budworms must first mine previous-years' needles (McGugan 1954; Shepherd 1992) and forage continuously within and between the crowns of trees to find current-year pollen cones and swelling buds (Sanders 1991). Many small budworms are lost during this dispersal stage (Miller 1958; Nealis and Lomic 1994; Nealis and Régnière 2009). I return to this key point in later sections.

As bud development proceeds, budworms enter the buds, construct feeding shelters and pass through four or five more instars (McGugan 1954; Nealis 1987; Nealis and Régnière 2014). As in all parts of the life cycle following egg hatch, budworms prefer a solitary habit during the feeding period and are reluctant to move from their feeding shelters as long as current-year foliage is available. Back-feeding on previous-years' foliage may occur in extremely high population 
Table 1. Host-trees and mean (range) outbreak periodicity and duration for major conifer-feeding budworms in North America.

\begin{tabular}{|c|c|c|c|c|}
\hline Characteristic & Spruce budworm & Western spruce budworm & $\begin{array}{l}\text { Two-year cycle spruce } \\
\text { budworm }\end{array}$ & Jack pine budworm \\
\hline $\begin{array}{l}\text { Hosts: Primary* } \\
\text { Secondary }\end{array}$ & $\begin{array}{l}\text { Balsam fir, white spruce } \\
\text { Black spruce, red spruce }\end{array}$ & $\begin{array}{l}\text { Douglas-fir } \\
\text { Grand fir, white spruce }\end{array}$ & $\begin{array}{l}\text { Subalpine fir, white/ } \\
\text { Engelmann spruce } \\
\text { Black spruce }\end{array}$ & $\begin{array}{l}\text { Jack pine } \\
\text { Red pine }\end{array}$ \\
\hline $\begin{array}{l}\text { Outbreak: Periodicity } \cong \\
\text { mean (range) }\end{array}$ & $\begin{array}{l}\text { Western Québec and Ontario, } 70 \text { years } \\
(27-138)^{1} \\
\text { Québec and New Brunswick, } \\
41 \text { years }(19-79)^{1} \\
\text { Western Ontario, } 33 \text { years } \\
(15-62)^{2} \\
\text { Québec, } 42 \text { years }(28-65)^{3,4} \\
\text { Northern Québec, } 37 \text { years } \\
(13-110)^{5} \\
\text { British Columbia, } 22 \text { years } \\
(14-28)^{6,7}\end{array}$ & $\begin{array}{l}\text { New Mexico, } 33 \text { years }(17-70)^{9} \\
\text { Colorado, } 38 \text { years }(15-90)^{9} \\
\text { New Mexico, } 31 \text { years }(15-100)^{10} \\
\text { Colorado, } 39 \text { years }(33-79)^{11 \perp} \\
\text { British Columbia, } 30 \text { years } \\
\quad(26-37)^{12 \perp}\end{array}$ & $\begin{array}{l}\text { British Columbia, } 32 \text { years } \\
\quad(24-39)^{16} \\
\text { British Columbia, } 39 \text { years } \\
\quad(20-80)^{17}\end{array}$ & $\begin{array}{l}\text { Saskatchewan and } \\
\text { Manitoba, } \\
10 \text { years (NA) }{ }^{18} \\
\text { Wisconsin, 5,6, and } 10 \text { years } \\
\text { (NA) } \\
\text { Ontario, } 15 \text { years, } \\
(12-17)^{20}\end{array}$ \\
\hline $\begin{array}{l}\text { Outbreak: Duration } \\
\text { mean (range) }\end{array}$ & $\begin{array}{l}\text { British Columbia, } 12 \text { years }(6-20)^{6,7} \\
\text { Eastern Canada, } 9 \text { years }(1-25)^{8}\end{array}$ & $\begin{array}{l}\text { Colorado and New Mexico, } 11,13 \\
\text { years }(5-26)^{9,10} \\
\text { Pacific Northwest, } 12 \text { years }(8-16)^{13} \\
\text { Northern Rockies, USA, } 4.4 \text { years } \\
(1-30)^{14} \\
\text { British Columbia, } 8.4 \text { years } \\
(7-11)^{12 \perp} \\
\text { British Columbia, } 4.3 \text { years } \\
(1-13)^{15}\end{array}$ & $\begin{array}{l}\text { British Columbia, } 11 \text { years } \\
\quad(4-20)^{16,17}\end{array}$ & $\begin{array}{l}\text { Ontario, Michigan, } \\
\text { Wisconsin } \\
(2-4 \text { years })^{21} \\
\text { Ontario ( } 2-6 \text { years })^{20,22}\end{array}$ \\
\hline
\end{tabular}

${ }^{1}$ Blais (1983), ${ }^{2}$ Blais (1985), ${ }^{3}$ Boulanger and Arseneault (2004), ${ }^{4}$ Boulanger et al. (2012), ${ }^{5}$ Morin et al. (1993), ${ }^{6}$ Shore and Alfaro (1986), ${ }^{7}$ Burleigh et al. (2002), ${ }^{8}$ Gray (2013), ${ }^{9}$ Swetnam and Lynch (1989), ${ }^{10}$ Swetnam and Lynch (1993), ${ }^{11}$ Ryerson et al. (2003), ${ }^{12}$ Alfaro et al. (2014), ${ }^{13}$ Flower et al. (2014), ${ }^{14}$ Johnson and Denton (1975), ${ }^{15}$ Parfett et al. (1994), ${ }^{16}$ Zhang and Alfaro (2002), ${ }^{17}$ Zhang and Alfaro (2003), ${ }^{18}$ Volney (1988), ${ }^{19}$ Volney and McCullough (1994), ${ }^{20}$ Scarr et al. (2012), ${ }^{21}$ McCullough (2000), ${ }^{22}$ Nealis et al. (2003).

Tree species on which extensive and significant damage are observed in Canada.

$\cong$ Interval between initial years of observed damage in regional outbreaks.

${ }^{\perp}$ Calculated from reported means. 
densities, especially when the hosts are true fir (Abies Miller; Pinaceae), but it is distinctly less common when the hosts are spruce (Picea Dietrich; Pinaceae), Douglas-fir (Pseudotsuga Carrière; Pinaceae), or especially pine (Pinus Linneaus; Pinaceae) in which older foliage is exceptionally tough. In all cases, survival and fecundity are significantly reduced when budworm are forced to feed on previous years' foliage (Blais 1952; Dodds et al. 1996). In fact, the seasonal window of high nutritional quality of the host-plant for budworms is quite brief. There is a race to begin the feeding season because the quality of current-year foliage declines rapidly so that late-feeding budworms are also subject to reduced survival and fecundity (Lawrence et al. 1997; Nealis 2012). Pupation occurs near the final feeding site and adults emerge approximately one week later.

The only variation in this life cycle is for twoyear cycle spruce budworm which feed for a brief period in the spring of their first year, then settle into a new hibernaculum as a third instar, moult to a fourth instar, and enter a second diapause where they remain throughout the first summer, autumn, and second winter. They emerge in the spring of the second year to complete their life cycle (Mathers 1932; Shepherd 1961; Shepherd et al. 1995). A small proportion of univoltine budworm populations can be biennial (Harvey 1967), especially in western spruce budworm (Nealis 2005). The hybrid progeny of two-year cycle spruce budworm parents and univoltine parents of western spruce budworm can be either univoltine or biennial depending on photoperiod, indicating both heritable and environmental influences (Nealis 2005).

Adult budworms employ chemically similar, although species-specific, pheromones for mating (Silk and Kuenen 1988), which, combined with differences in moth phenology, serve to reduce potential hybridisation in sympatric species (Sanders 1991; Shepherd et al. 1995; Lumley and Sperling 2011; Nealis and Régnière 2014). Female fecundity is inversely related to local defoliation (Nealis and Régnière 2004a) and seasonal foliage quality (Lawrence et al. 1997; Nealis 2012). Our knowledge of adult behaviour is restricted to $C$. fumiferana but at a coarse level probably applies to all budworms considered here. Female moths oviposit at least half of their egg complement in the natal site irrespective of host condition provided that some needles are available. Moths are capable of long-distance, nocturnal flights with the direction and distance influenced by ambient meteorological conditions (Greenbank et al. 1980; Sturtevant et al. 2015).

\section{Behaviour of populations}

\section{Spatial and temporal patterns}

Historical evidence for budworm outbreaks has been reconstructed by study of growth rings in trees (e.g., Blais 1954, 1965a; Burleigh et al. 2002; Zhang and Alfaro 2002; Alfaro et al. 2014), lumber in old buildings (Krause 1997; Boulanger et al. 2012), insect remains in sediments (Simard et al. 2006), and defoliation surveys (Kettela 1983; Volney 1988; Parfett et al. 1994; Simpson and Coy 1999). These reveal that the spruce budworm has been resident in northern forest ecosystems of Canada for at least 8500 years and outbreaks have been recurrent for at least the past four centuries. There is also evidence of outbreaks of western and two-year cycle spruce budworms for several centuries (Zhang and Alfaro 2002; Alfaro et al. 2014). Interpreting these patterns assembled from a combination of direct and indirect evidence gathered at different scales and variable sampling intensities is hazardous in detail (Régnière and Lysyk 1995) but nonetheless represents our best evidence of historical population patterns.

Blais $(1954,1965 \mathrm{a}, 1983,1985)$ used tree rings as indicators of spruce budworm outbreaks across the southern boreal forest of eastern Canada and concluded that outbreaks have been regional in scale but not clearly periodic as the intervals between outbreaks for a given location were highly variable (Blais 1968). Royama (1984) was convinced of a regular periodicity of $\sim 35$ years in the historical record and argued the unusually long intervals between outbreaks observed by Blais were the result of an undetected outbreak in the late 19th century for which there is now some evidence (Morin et al. 1993). But even without this speculative correction, most of the historical data compiled subsequent to Blais' research report a regular outbreak interval of 33-42 years albeit with considerable range in all datasets. More limited data from the extreme western range of 
C. fumiferana indicate a shorter interval of 22 years (Table 1). Overall the historical record for spruce budworm suggests a low frequency periodicity synchronised over a wide geographic range.

Evidence of outbreaks in western spruce budworm has been reconstructed from tree rings in New Mexico, United States of America (Swetnam and Lynch 1993), Colorado, United States of America (Swetnam and Lynch 1989; Ryerson et al. 2003), Pacific Northwest, United States of America (Flower et al. 2014), and British Columbia, Canada (Campbell et al. 2006; Alfaro et al. 2014). Here, too, there is evidence of regional-level outbreaks that share large-scale patterns for several centuries. As in spruce budworm, western spruce budworm outbreaks occur at 30-year to 40-year intervals with considerable regional range (Table 1). A series of data for two-year cycle spruce budworm from northern British Columbia suggests an outbreak interval of 32 years (Zhang and Alfaro 2002, 2003), a curiosity since this interval represents only half as many generations as the comparable interval in the one-year cycle budworms.

The duration of these low frequency outbreaks of conifer-feeding budworms is difficult to estimate from historical records because it varies spatially with geographic conditions (Kemp et al. 1985; Shepherd 1985), the methods and assumptions of the measurements (Alfaro et al. 1982), and the scale of observation (Gray 2013). Durations estimated from dendrochronologies are usually longer than those estimated from direct observation of defoliation for the same species in the same area. Mean outbreak duration for C. fumiferana is approximately nine years in eastern and 12 years in western Canada, but varies from a few to as many as 25 years in all regions (Table 1; Candau et al. 1998; Gray et al. 2000). The duration of western spruce budworm outbreaks is similar to spruce budworm outbreaks (Swetnam and Lynch 1989, 1993; Flower et al. 2014) although apparently is shorter in the northern portions of the range where outbreaks usually last less than 10 years and often no more than four years (Table 1; Johnson and Denton 1975; Maclauchlan et al. 2006; Alfaro et al. 2014).

An informative variation to these low-frequency, persistent outbreak patterns is the jack pine budworm. The historical record on this species is restricted to survey data from the 20th century but even with this direct evidence, patterns are irregular and currently changing. Volney (1988) proposed a 10-year periodicity for jack pine budworm outbreaks in the Prairie Provinces of Canada but this was confounded with the periodicity of forest fires, which influence this system significantly. Regardless, this apparent historical pattern has changed because outbreaks of jack pine budworm have been essentially absent from the prairie region since Volney's analysis and have become recurrent, if not yet periodic, more than $1000 \mathrm{~km}$ east in Ontario, Canada (Scarr et al. 2012; Hughes et al. 2014). Surveys from Wisconsin, United States of America, revealed highly variable periodicities averaging from five to 12 years depending on specific site conditions (Volney and McCullough 1994). An associated characteristic of jack pine budworm outbreaks is their short duration, lasting only two to six years at the regional level (McCullough 2000; Scarr et al. 2012) and even fewer for individual trees within infested stands (Nealis et al. 2003).

Despite high variability in the range of outbreak periodicity and duration at the local level, budworm outbreaks appear synchronised over large areas via several potential mechanisms including correlated, large-scale weather-related perturbations and dispersal of moths (Cooke et al. 2007). Once again, deviations from this generalisation are informative. Synchrony of spruce budworm in the contiguous, balsam-fir rich forests of eastern Canada is clear (Royama 1984) but less so in the more mixed, climatically diverse forests of central Canada (Blais 1985; Candau et al. 1998), and even less so in the sinuous, river-valley spruce forests of northwestern Canada (Burleigh et al. 2002). During the last outbreak, observed defoliation in Canada began and ended in regions east of $-80^{\circ}$ longitude 10 years before these same events further west (Fig. 1A, B; Régnière and Nealis 2007). Synchrony in outbreaks of western spruce budworm is limited to smaller geographic areas (Alfaro et al. 2014) with occasional overlap among adjacent areas otherwise distinct (Swetnam and Lynch 1989, 1993; Ryerson et al. 2003). This different pattern may be related to western spruce budworm's broad latitudinal distribution over mountainous terrain, which would constrain moth dispersal and result in more localised weather effects than would 
be the case for the spruce budworm. The long duration and greater amplitude of outbreaks in both spruce budworm and western spruce budworm makes apparent synchrony over large areas in these species likely. In jack pine budworm with short-duration outbreaks, large-scale synchrony is less apparent with the extensive outbreak of the 1980 s being the notable exception (Fig. 1C).

Most studies of budworm outbreak patterns cited here emphasise mean values, which reinforce the perception of the regularity of cycles with characteristic durations. However, there is also variation in outbreak behaviour that contains relevant information for understanding dynamics. For example, catastrophic forest change resulting from high mortality of dominant trees is not universal in any budworm system and actually atypical in most. Today's northern forests are shaped by the legacies of past disturbance caused by budworms. Severe outbreaks may be ecologically transient at one scale but transformative at another. Since variation in the frequency, severity, and duration of outbreaks determines their ecological and socio-economic impacts at all spatial and temporal scales, understanding how and why outbreaks vary in these parameters helps prepare for future disturbances and identification of ecosystem-level indicators of climate or land-use changes in prevailing forest disturbance regimes.

\section{Population dynamics}

Widespread, severe damage to trees in mature stands was the most evident, empirical information available to early investigators of population dynamics. A heuristic explanation emerged in which outbreaks occurred in homogeneous, mature stands dominated by preferred host species. The abundant food source permitted rapid population growth under favourable environmental conditions. Persistent defoliation reduced foliage and killed the most vulnerable trees. The resulting reduction in foliage, in turn, forced decline in spruce budworm populations (Blais 1983). Outbreak cycles were thus related to the average period between destruction and regeneration of vulnerable stands within a resilient forest system. This was the basis for synthetic models of spruce budworm dynamics (Ludwig et al. 1978; Jones 1979) and conceptual explanations of associated forest dynamics (Baskerville 1975).
This resource-driven perspective appealed to forest managers because of its cause-and-effect relationship to stand attributes. It led to clear management decisions as intervention was required if severe impacts were to be avoided in highly vulnerable stands (MacLean 1996). This perspective also explained apparent, increased severity and extent of outbreaks in the 20th century as selective harvesting, regeneration, and fire-suppression increased the abundance of the most susceptible host species for spruce budworm (balsam fir) (Blais 1983), western spruce budworm (Douglas-fir) (Anderson et al. 1987; Swetnam and Lynch 1993), and jack pine budworm (jack pine) (Volney 1988).

There were, however, problems with this explanation. First, not all outbreaks result in catastrophic reduction in basal area of susceptible tree species for spruce budworm (Morris 1963a; Alfaro et al. 2001) and especially for jack pine budworm (Gross 1992) and western spruce budworm (Alfaro et al. 1982; Van Sickle 1987). Second, even in the case where forest stands were severely impacted, the length of the outbreak cycle, 30-40 years, was not long enough to replace a northern conifer forest. Other significant ecological factors must be modifying this periodicity.

The Green River Project in New Brunswick, Canada, introduced a quantitative life system approach to spruce budworm population dynamics (Morris 1963a). The data were used in several interpretations of population ecology (Morris 1963b; Jones 1979; Royama 1984) but all featured eruptive, periodic outbreak dynamics driven by lagged, density-related processes associated with trophic interactions modulated by weather and confounded by moth dispersal. Two paradigms emerged; one in which spruce budworm populations rapidly switch between multiple equilibria as a function of resource availability (Ludwig et al. 1978) and an alternative view in which populations oscillate gradually with a unique conditional equilibrium that varies according to the current state of different forcing agents such as natural enemies (Royama 1992). The ensuing debate has drawn useful attention to how the relative strength and direction of trophic interactions influence dynamics (Cooke et al. 2007; Sturtevant et al. 2015). I return to this in detail after first considering the pervasive effect of weather and the obfuscating effect of moth dispersal. 
Fig. 3. Time and space scales (log) of northern conifer forests and their relationship to ecological processes that influence the population dynamics of budworms. Dispersal of budworm larvae and moths provide linkage between macroscale atmospheric processes and microscale landscape processes. The results of microscale processes such as larval dispersal vary among jack pine budworm, spruce budworm, and western spruce budworm systems whereas natural enemy foraging and community composition are similar over all scales (adapted from Peterson et al. 1998).

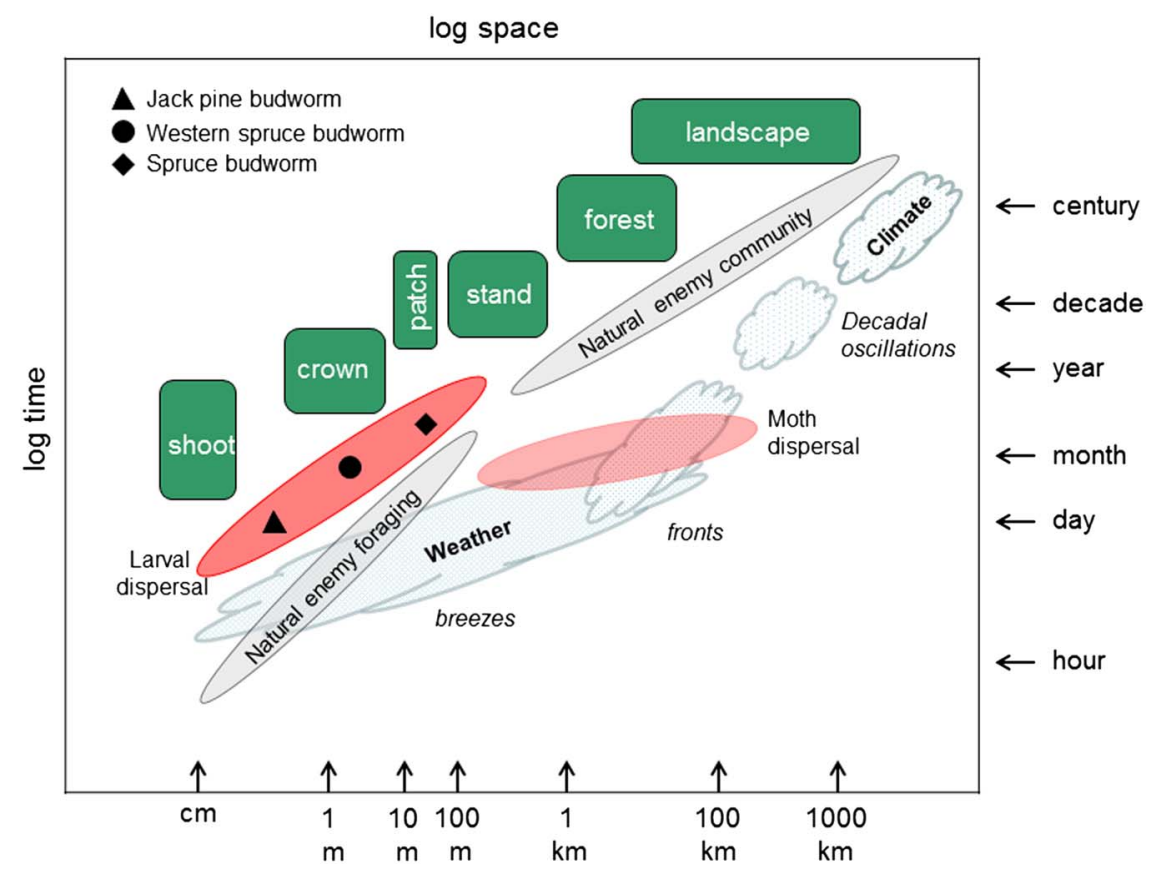

\section{Influence of climate and weather}

Climate often defines the primary environmental range of insects via the cumulative and cross-scale effects of local weather on populations (Fig. 3). A simple, explanatory relationship between weather and budworm outbreaks, however, remains elusive. The influence of weather on population dynamics of budworms is more complex than direct, modulating rather than driving rates of change and absolute levels of population densities at multiple scales through its effect on ecological relationships that determine fecundity and survival. Weather is an environmental context for understanding variability in the intrinsic drivers of population change.

Wellington et al. (1950) analysed synoptic weather patterns in northern Ontario and concluded that spruce budworm outbreaks were preceded by years with relatively warm, dry summers and fewer storms. Supporting evidence was found for spruce budworm elsewhere by Greenbank (1956) and Pilon and Blais (1961), and for western spruce budworm by Thomson et al. (1984). All suggested these conditions favour foraging by larvae and moth dispersal. Statistical approaches identified specific meteorological variables correlated to outbreak behaviour of jack pine budworm (Clancy et al. 1980), western spruce budworm (Kemp et al. 1985) and spruce budworm (Candau and Fleming 2005; Gray 2013) but explanatory ecological processes were difficult to interpret or returned contrary results (Swetnam and Lynch 1993; Flower et al. 2014). This ambiguity is not surprising given the formidable number of weather variables that can enter an analysis and risk spurious inferences (Royama 1984) or the differences in data sources and analytical techniques among studies (Gray 2013). These empirical studies have most value in synthesis of large datasets and identification of likely and unlikely hypotheses. For example, most historical analyses conclude the importance of weather is contingent on location-specific forest composition, in particular, abundance of susceptible hosts (Shepherd 1959; Blais 1968; Candau and 
Fleming 2005; Gray 2013) but becomes a more dominant influence at the margins of budworms' ranges (Blais 1968; Volney and Fleming 2007; Régnière et al. 2012b).

Understanding population dynamics within a species' range requires consideration of the effects of weather on contemporaneous trophic interactions (Volney and Fleming 2007; Gray 2008). Process-oriented phenology models re-scale seasonal events in an insect's life history from calendar to physiological time. Phenology models for budworms vary from simple heat unit accumulations (Shepherd 1961; Lysyk and Nealis 1988) to nonlinear functions incorporating individual variation for all life stages (Lysyk 1989a; Régnière et al. 2012b; Nealis and Régnière 2014). They have been used to investigate ecological relationships between budworms and their tree hosts (Thomson et al. 1984; Lysyk 1989b; Volney and Cerezke 1992; Thomson and Benton 2007; Nealis 2012) and natural enemies (Nealis 1988; Quayle et al. 2003) as well as to predict shifts in geographic range with climate change (Régnière et al. 2012b).

\section{Dispersal of moths and recruitment of eggs}

Both male and female budworm moths disperse. The direct contribution of female moths actively transporting eggs has received most attention (Greenbank et al. 1980; Royama 1984) but dispersing male moths may contribute to increase in populations by enhancing mating success at low population densities (Régnière et al. 2012a). Moth dispersal appears to be more weather than population related (Greenbank et al. 1980; Anderson and Sturtevant 2011) and there is credible anecdotal evidence that immigration has been the source of sudden increases in local population densities (Wellington et al. 1950; Greenbank 1957; Dobesberger et al. 1983). Whether dispersal leads to persistent new outbreaks or populations return to their former, low-density state in these situations depends on local conditions. Nonetheless, the likelihood of moth immigration in the first place is more dependent on location of the receiving area relative to a source with respect to direction of prevailing wind during the adult period, than on the ecological suitability of the forest receiving budworms (Greenbank 1957; Anderson and Sturtevant 2011). Moths have limited, if any, choice as to where they land. So the extent to which large-scale patterns are the result of moth dispersal remains controversial in theory (Royama et al. 2005) and problematic in practise (Sturtevant et al. 2013) because the net effect of observed dispersal activity in a given location is not obvious. What is clear, however, is that the capacity and inclination for moths to migrate long distances is a phylogenetic trait common to all Choristoneura which adds significant potential for stochastic influence on local rates of change and results in a meta-population structure of sustained and synchronised outbreaks over a regional scale for all species (Fig. 3; Cooke et al. 2007).

\section{Trophic relationships}

\section{Top-down: the influence of natural enemies}

Surveys of natural enemies such as parasitoids, predators, and pathogens are available from throughout the ranges of most budworms. Parasitoids have been particularly well studied and there are recent identification keys and tables summarising associations with the different budworm species (Huber et al. 1996; O’Hara 2005; Bennett 2008; Fernández-Triana and Huber 2010). The number of parasitoid species found reflects the search effort and so the greatest number of the more than 200 species recorded from Choristoneura in North America is associated with $C$. fumiferana and the lowest number for the four species considered here is from the lesser known C. biennis (Fernández-Triana and Huber 2010). The impressive diversity of parasitoids associated with spruce budworm from one intensively sampled area has been analysed as a food web comprising at least five trophic levels from the balsam fir producer through the budworm herbivore to tertiary hyperparasitoids (Eveleigh et al. 2007).

Despite the complexity of natural enemy assemblages, some useful qualitative generalisations are possible. First, while there is a rich, potential diversity of parasitoids attacking conifer-feeding Choristoneura, there are only a few species that are relatively abundant and these same species are abundant throughout the continental range of Choristoneura (Fig. 3). Second, the most common parasitoid species parasitise all of the budworm species considered here (Huber et al. 1996; O’Hara 2005; Bennett 2008; Fernández-Triana and 
Huber 2010) and several are true generalists, attacking other Lepidoptera hosts. The generalist characteristic of the parasitoid fauna attacking budworms has led to the notion that most parasitoids in budworm outbreaks are opportunistic (Eveleigh et al. 2007) and have a limited ability to respond numerically to increases in budworm abundance because of their reliance on alternative hosts to satisfy their seasonal life history requirements (Miller 1963; Blais 1965b; Sanders 1991). The few parasitoid species with seasonal life histories that do match budworms', such as Apanteles fumiferanae Viereck (Hymenoptera: Braconidae) and Glypta fumiferanae Viereck (Hymenoptera: Ichneumonidae), are ubiquitous and common but it is debatable whether their rates of attack track, rather than drive, rates of change in their host populations (Miller 1963; Royama 1984; Nealis 1988). Another potential limit to strong numerical responses of primary parasitoids is the diverse set of secondary parasitoids and hyper-parasitoids that attack these parasitoids during the outbreak period (Eveleigh et al. 2007).

A less obvious faunal pattern for parasitoids of budworms is the association of particular species with the density, or outbreak phase, of the budworm population. The relative diversity of the parasitoid fauna changes as outbreaks progress (Eveleigh et al. 2007) and apparent parasitism by a few species such as Meteorus trachynotus Viereck (Hymenoptera: Braconidae), increases during collapse of budworm populations (Miller 1963; Blais 1965b; Nealis 1991). Endemic spruce budworm populations are attacked by very few of the parasitoid species common at higher densities but, interestingly, are attacked by a completely distinct set of species rarely encountered in outbreak populations (Miller and Renault 1976; Eveleigh et al. 2007).

Similarly, the importance of predators varies over the outbreak cycle. Several species of specialist migratory birds and small mammals have negligible impacts on outbreak populations (Morris et al. 1958; Mattson et al. 1968) despite initial numerical responses as budworm populations increase (Holmes et al. 2009). The impact of bird predation is inversely related to budworm densities (Campbell et al. 1983). The prevailing hypothesis is that bird predation has an important, perhaps regulatory, influence on low-density budworm populations although critical data remain unavailable (Sanders 1991; Venier and Holmes 2010). A qualitative analysis of bird predation in budworm dynamics argued that the role of predators gains more insight when viewed as functional (e.g., body size), as opposed to taxonomic, groups (Holling 1988). As is becoming apparent with parasitoids, guilds of bird predators have distinct impacts at different budworm densities with distinct consequences on population behaviour.

Pathogens also have been well studied in budworm populations (Eveleigh et al. 2007) but their role in the ecology of budworms is equivocal. Royama (1984) evoked a potential suite of diseases as the "fifth agent" contributing to population collapse observed in the Green River Project but it is not clear whether these were actual pathogens or the result of insufficient information in the original study. As with parasitoids, the same pathogens or their homologues have similar roles in the different budworm systems. Common pathogens such as Nosema Nägeli (Microsporida: Nosematidae) become more prevalent over the course of an outbreak (Régnière 1984; van Frankenhuyzen et al. 2011; Eveleigh et al. 2012) but their effects on individuals are generally sublethal and their impact on rates of population change enigmatic (Wilson 1987; Eveleigh et al. 2012). Fungal epizootics are infrequent and localised (Perry and Régnière 1986). Detailed molecular characterisation of several viruses isolated from spruce budworm and western spruce budworm show them to be essentially variants of otherwise similar genomes (Arif et al. 1986; Graham et al. 2008; Thumbi et al. 2013); more evidence of the close phylogenetic lineage of these budworms. Baculoviruses are widely distributed in budworm populations but their prevalence is very low and epizootics are rare to absent in $C$. fumiferana (Cunningham and Kaupp 1995). They appear more frequent in C. occidentalis populations but only at exceptionally high densities where their impacts are transient (Nealis et al. 2015).

The association of generalist natural enemies common to all budworms over their continental range suggests that natural enemies in the budworm system respond to, rather than determine, the population density of budworms; the "birdfeeder" effect whereby high-density budworm populations attract or enable a greater number of 
Fig. 4. Idealised budworm population cycle showing change in budworm density and associated change in trophic interactions in different phases. Budworm populations (grey) increase with an increase in resource availability (green) although this increase is dampened by strong, persistent top-down effects by specialised natural enemies (red). Outbreaks occur when host-related survival increases budworm density and specialised natural enemies effective at low population densities are replaced by generalists that inflict relatively low levels of generation mortality (purple). Collapses occur when persistent damage by budworm feeding reduces host-related survival in combination with increases in mortality by a small subset of natural enemies.

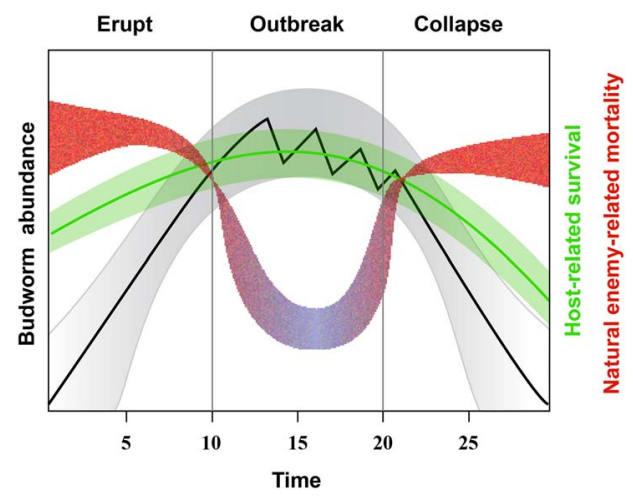

widespread generalist natural enemies to exploit dense populations (Eveleigh et al. 2007). The third pattern of a few species of natural enemies commonly associated with collapsing or endemic populations, however, suggests that the critical relationship between natural enemies and budworms emerges near transition points in the outbreak cycle where budworm densities tend to increase or decrease relatively rapidly through several orders of magnitude as a result of significant trends in generation survival and recruitment (Fig. 4).

The difficulties of inferring this transient but critical role of natural enemies from population measurements has been long recognised but proposed solutions based on direct sampling seem formidable (Royama 2001). A qualitative working hypothesis using comparative analysis and the context of trophic interactions (Cooke et al. 2007) offers a robust alternative that makes use of the weight of evidence provided by uncommonly rich historical knowledge available for budworms. I return to this point in the final section.

\section{Bottom up: influence of the resource}

Blais (1985) stressed the central importance of balsam fir in the location and severity of outbreaks of $C$. fumiferana. Certainly most analysis of historical records find a clear relationship between growth reduction or defoliation, proxies for spruce budworm population density, and some measure of balsam fir abundance (e.g., Gray 2013). Similar associations between outbreaks and abundance of preferred host trees are found in the other Choristoneura species (Campbell 1993; Shepherd et al. 1995; McCullough 2000; Maclauchlan et al. 2006). While it may be an obvious prerequisite for outbreaks to occur where host-trees are abundant, the extent to which the influence of the preferred host pervades every aspect of the life history and ecology of conifer-feeding budworms, with significant effects on outbreak characteristics, may be less clear. Viewed as a cross-scale factor, the ecological relationship between budworms and their hosts tells us much about the similarities and differences in their dynamics.

At the coarsest scales, basal area of susceptible host species is repeatedly confirmed as the dominant indicator of likely infestation and significant damage (Turner 1952; MacLean 1980; Bouchard et al. 2005; Gray 2013). Thus, stand composition and age (size) of host trees emerge as significant factors over other site-related indicators (Bergeron et al. 1995; MacLean and MacKinnon 1997) although at slightly larger scales, abiotic environmental gradients may become evident (Magnussen et al. 2004; Bouchard and Auger 2014). The presence of non-host trees reduces impacts whether they are mixed in the stand (Su et al. 1996) or the stand is embedded in a landscape-scale matrix of host and non-host stands (Campbell et al. 2008; Bouchard and Auger 2014). But is it simply food supply? Certainly, foliage depletion can reduce survival and fecundity by depriving larvae of food but these are transient, first-order effects not associated with population collapse (Morris 1963c; Royama 1984; Nealis and Régnière 2004a; Régnière and Nealis 2007).

Qualitative changes in the nutritional adequacy of host foliage or active host responses to defoliation have been proposed as correlates of population decline, especially in western spruce budworm and jack pine budworm (Campbell 1993); 
i.e., host quality does matter. A defining phylogenetic constraint for all of these budworms is their requirement to feed on rapidly growing, current-year shoots when nitrogen availability is greatest (White 1993). Outside this relatively narrow seasonal window of nutritional adequacy, current-year foliage is more difficult to exploit. In early spring, buds are hard, enclosed by scales, and difficult to penetrate (Shepherd 1992; Nealis and Lomic 1994; Nealis and Nault 2005). In mid-summer, development of foliage is characterised by decreasing fitness of budworms associated with increased lignification of current-year foliage (Lawrence et al. 1997; Nealis 2012). However, these are normal, seasonal changes in the physical characteristics of the foliage, whereas most of the studies of host quality examine plant-chemical and physiological relationships to identify either constitutive or induced mechanisms of resistance (Clancy 2002). For good experimental reasons, this work often uses artificial diet containing extracted, controlled nutritional supplements (e.g., Albert and Bauce 1994; Delvas et al. 2011) and so remove the seasonal physical characteristics of intact foliage. Overall results show that aside from the dominant importance of nitrogen, variability in host-plant chemistry has minor negative effects on the performance of budworms and there is little evidence of induced plant responses with significant negative feedbacks to population rates of change (Mattson et al. 1991). A simpler, more direct ecological relationship between budworms and their hosts lies in the distribution, abundance, and physical characteristics of the host resource and its effect on recruitment of eggs at the coarse scale and the survival of small budworm larvae at finer scales.

\section{Summer dispersal of neonates and overwinter survival}

All budworms disperse at least twice before feeding; first following hatch in summer to find hibernation sites and then the following spring to forage for food. Their likelihood of surviving these events is their risk of dispersal (Nealis 2003). This risk varies with dispersal distance, weather conditions under which dispersal occurs, and the success of these small larvae, first in finding suitable hibernation sites and then adequate feeding sites. In between these dispersal events, budworms must survive several months of variable weather without feeding or imbibing water. The details of this sequence are important to understand for the comparative analysis.

Moths lay eggs on foliage at the periphery of the tree crown. When they hatch, larvae react positively to light except at warmer temperatures $\left(>29^{\circ} \mathrm{C}\right)$ at which they become photonegative (Wellington and Henson 1947). If walking toward the light, many reach the branch tips and drop, suspended on a silken thread. The risk of this dispersal event, however, is relatively low because summer weather in northern forests tends to be strongly convective and downdrafts force dislodged budworms downwards where they are likely to be intercepted by the lower branches of the conical-shaped crowns of their host tree; even more so for larvae dispersing during warmer summer days when they are photonegative. So, dispersal of first-instar budworms is mostly within the crown of the tree (Régnière and Fletcher 1983).

When budworms encounter rough surfaces, the photic stimulus is replaced by a tactile stimulus that results in settling and constructing a sheltered hibernaculum (Wellington and Henson 1947). The net effect is that neonates tend to establish their overwinter sites more interior and lower in the crown than where eggs were laid (Régnière et al. 1989). The final distribution of overwintering budworms, however, varies significantly among species because of the interaction between their common behaviour to settle in sheltered locations and the specific characteristics of their associated host trees in providing such locations. Balsam fir has woody bracts on its branch tips, which are preferred overwintering sites for spruce budworm (Blais 1952; Greenbank 1963). Spruces have pronounced leaf-pegs on branch internodes (Farrar 1995), which also provide sheltered niches. The result is that most $C$. fumiferana find suitable overwintering sites along the foliated branches close to where eggs were laid and do not need to disperse a great distance to find overwinter sites on the tree bole (Miller 1958). This is also likely true for two-year cycle spruce budworm in the spruce-fir forests of western Canada. Jack pine, by comparison, produces no such woody structures and its slender peripheral shoots have smooth bark. Pronounced bark flakes and grooves providing sheltered niches only become common on the basal branch surfaces and tree bole of jack pine, which is where most jack pine budworm overwinter 
(Nealis and Lysyk 1988). Douglas-fir also has fewer suitable overwintering sites on its branch tips compared to the deeply furrowed surfaces near the branch base and especially on the tree bole. Similarly, most western spruce budworm overwinter on the bole than elsewhere (McKnight 1969; Nealis and Régnière 2009). Thus while all budworms have a common need to find suitable locations to overwinter, their ultimate choice is determined by the specific surface features of their host-trees.

Wellington and Henson (1947) stressed the importance of a sheltered niche in protecting spruce budworm in hibernacula from desiccation during the warm days of late summer and autumn. Direct field measurements found a positive correlation between survival of spruce budworm and their propensity to choose hibernation sites on complex branch surfaces (e.g., bracts, lichen mats) compared to smooth-barked shoots (Régnière and Duval 1998). Exposure to relatively warm temperatures in the laboratory during the prediapause period increased mortality by desiccation (Bauce and Han 2001) and accelerated loss of lipid and glycogen reserves so budworms also were more vulnerable to mortality later during the postdiapause period (Han and Bauce 1998). This negative effect of warm summer temperatures on subsequent overwinter survival is apparent in field populations but the effect can be reduced in shelters that buffer weather conditions (personal observation). So, the behaviour of first-instar budworm in finding protected overwinter niches reduces the negative effects of exposure to inclement conditions on their survival. But this adaptive syndrome results in a trade-off between improved overwinter survival and increased risk of dispersal the following spring.

\section{Spring dispersal and survival during foraging}

Emerging, second-instar budworms are strongly photopositive throughout the foraging period (Wellington and Henson 1947). This is what brings them to the branch tips in search of feeding sites. Weather during the spring dispersal period is typically cooler and more turbulent than during first-instar dispersal the previous summer resulting in extensive inter-tree dispersal of larvae as they balloon on silk threads between tree crowns (Beckwith and Burnell 1982; Régnière and Fletcher 1983). As mentioned, all univoltine budworms considered here emerge in the spring in advance of bud-flush so it is normal that they use temporary alternatives including pollen cones and previousyear needles (Sanders 1991). The availability of these critical, alternative resources varies among host species and over time affects patterns of survival of their budworm guests and, in turn, has consequences for respective dynamics.

Coniferous trees periodically produce pollen cones early in the season before vegetative buds flush. These are favoured by foraging budworms as they bridge the period between spring emergence and bud-flush (Blais 1952; Greenbank 1963; Nealis and Lomic 1994). Pollen cone production is most frequent in mature trees growing in open situations and within a species, production of pollen cones tends to be synchronised regionally (Blais 1952; Greenbank 1963; Hughes et al. 2014). The relative importance of pollen cones to spring emerging budworms depends on alternative resources of the host trees, essentially previous years' needles that can be mined or tied together with silk to form a protected feeding site. Spruce budworm and western spruce budworm readily mine older needles in the absence of pollen cones (McGugan 1954; Shepherd 1992; Trier and Mattson 1997; Nealis and Nault 2005). Jack pine budworm, however, is unable to mine the needles of jack pine and so pollen cones are critical during its spring dispersal period (Nealis and Lomic 1994). Fortunately for jack pine budworm, jack pine has a high propensity to produce pollen cones (Nealis et al. 2003; Hughes et al. 2014). So an adaptive syndrome for all budworm species that mitigates the problems of precocious emergence is the temporary use of previous years' needles and pollen cones when available.

What happens to these early-season feeding sites during outbreaks emphasises the differences among host tree species and consequent dynamics of their associated budworms. When defoliated, conifers reduce pollen cone production abruptly (Blais 1952; Nealis et al. 2003; Hughes et al. 2014). This has an immediate impact on jack pine budworm that now must forage more extensively for scarce resources critical to its survival (Nealis and Lomic 1994). By comparison, the immediate impact of fewer pollen cones on spruce budworm and western spruce budworm is less dire because these species can mine needles and their hosts compensate for defoliation by producing even 
more vegetative buds (Shepherd 1992; Nealis and Régnière 2004b). Nonetheless, severe defoliation by western spruce budworm reduces needle density of the host, which similarly increases foraging dispersal in subsequent generations (Nealis and Régnière 2009). There is no evidence of such tree-level effects between spruce budworm and its spruce-fir hosts.

Continuous foraging during the spring emergence period may increase the likelihood that budworms will find fresh buds (McGugan 1954; Shepherd 1992; Nealis and Lomic 1994) but at the cost of an increased risk of dispersal at the stand level that also differs among systems (Régnière and Nealis 2008). Spruce budworm and twoyear cycle spruce budworm occupy boreal and cordilleran spruce-fir forests where their shadetolerant hosts characteristically develop full crowns forming dense stands with a high degree of canopy closure at maturity. By comparison, western spruce budworm and jack pine budworm use hosts that are less shade tolerant and have more open crowns and sparser canopy densities in the dry sites they occupy (Farrar 1995). These features mean that between-crown dispersal of budworm characteristic of the spring emergence period is more hazardous to western spruce budworm and jack pine budworm than to spruce budworm as it is more likely to result in larvae landing off the host. Field measurements show a high rate of loss of early-stage larvae in jack pine budworm and western spruce budworm (Nealis and Lomic 1994; Nealis and Régnière 2009). The comparable situation only occurs in spruce-fir forests once the stand has become thinned by prolonged defoliation and significant gaps develop that change the characteristics of the stand to one that resembles the more open condition of Douglas-fir and jack pine stands (Régnière and Nealis 2008).

To summarise, all early-stage budworms share the same adaptive syndrome; find a sheltered niche to overwinter and emerge early in the spring to forage for the earliest available resources. But the population outcome can be different among budworm species because of the interaction of these dispersal events with the distinct characteristics of their respective host trees. Budworms exploiting jack pine and Douglas-fir overwinter on rough surfaces in the interior of the crown and so must travel further to hibernate in the summer and again in the spring to forage for resources than budworms exploiting spruce and fir. Differences in risk of dispersal are accentuated at the stand level as jack pine and Douglas-fir trees have sparser crowns and density of trees per ha is typically lower than in spruce-fir stands. These normal differences among tree and stand characteristics become magnified as delayed negative feedbacks from defoliation first reduce pollen cone and needle density at the tree level and eventually create resource gaps at the stand level as trees die (Fig. 3).

Are these relative differences in the ecological relationships between budworms and their respective hosts significant to population dynamics? Both theory and empirical evidence would suggest so. In theory, lagged, reciprocal, densitydependent responses between a consumer and its resource can generate outbreak cycles (Royama 1992). The empirical evidence of large-scale outbreak dynamics of these species shows the same graded response in their defining parameters as the specific budworm-host ecological relationships summarised here. Spruce budworm, with its low frequency, long duration, and extensively synchronised cycles correlates to the slow negative feedbacks of the host to the effects of budworm density (Régnière and Nealis 2008). At the other extreme, the short-lived, relatively high-frequency, vaguely periodic and more spatially fragmented nature of jack pine budworm outbreaks correlates to the near immediate reduction of critical pollen cones with subsequent impact on jack pine budworm survival following the first episode of significant defoliation (Nealis and Lomic 1994; Nealis et al. 2003). Outbreaks of western spruce budworm are certainly more regular and long-lived than those of jack pine budworm but there are regional differences that make generalisations regarding extensively synchronised and persistent outbreaks less convincing than those of spruce budworm in eastern Canada. The final section examines how these bottom-up ecological relationships interact with top-down factors to shape the eruptive behaviour of all budworms.

\section{Integrating trophic interactions}

Cooke et al. (2007) present a graphical model in which spruce budworm population cycles are induced by delayed, density-related negative 
feedbacks among three trophic levels. This tritrophic concept is dissected here to reveal marked changes in the interaction between bottom-up and top-down factors as the population cycle proceeds from endemic to outbreak to collapse (Fig. 4).

Within suitable climatic zones, budworm survival is favoured in forests with high foliage densities characterised by large, overlapping tree crowns with abundant current-year buds augmented by pollen cones. Forest growth is a relatively slow-moving variable (Fig. 3) so the change toward a condition that favours budworm survival takes many budworm generations. But in the absence of other disturbances, the trend toward improved resource conditions will proceed. Sustained increase in budworm populations commensurate with resource improvement, however, depends on more than foliage and good weather as low density budworm populations are subject to very high rates of mortality from natural enemies (Sanders 1991; Eveleigh et al. 2007) as well as by reduced mating success (Régnière $e t$ al. 2012a) that curb sustained increases in density.

Over the immense biogeographic range characterised by extensive northern conifer stands, stochastic elements will result in areas where the coincidence of abundant foliage and limited parasitoid activity permit some increase in budworm densities over a few generations. With higher local densities, there will be more dispersing moths, homogenising the local increase in rate of recruitment over a larger area. Because of the persistent impact of natural enemies, however, even favourable bottom-up conditions do not necessarily propel budworm densities to outbreak. Favourable local conditions must be sustained for several generations for an outbreak to develop locally, at least in C. fumiferana (Royama 1984). But relaxation of top-down mortality dominating at low densities will happen somewhere in the extensive geographic range as the bottom-up conditions improve for budworm and the importance of natural enemies effective in endemic populations diminish. This change in the tritrophic interaction reinforces further increase in survival, recruitment, and population density to outbreak levels (Fig. 4).

Conifer hosts are tolerant of feeding budworms as these herbivores are essentially grazers of non-vital tissues. Occasional, severe defoliation causes first-order reductions in population densities through a combination of starvation, reduced fecundity, and net emigration so defoliation the next year is seldom as severe. An important change occurs, however, in the tri-trophic interaction as budworm populations reach outbreak levels. The natural enemies associated with endemic populations are replaced functionally at outbreak levels by a different guild of common, generalist species that collectively impose a fairly consistent but relatively low level of mortality during the outbreak. This absence of strong, variable top-down effects that were present during the increase phase permit rapid recovery of budworm populations from short-term, negative bottom-up effects such as severe defoliation so that outbreaks are sustained, sometimes for more than a decade (Fig. 4).

However, as cumulative damage from budworm becomes significant, the bottom-up interaction changes systematically with significant impacts on budworm survival (Fig. 5). First, defoliation reduces pollen cone production in all conifers. This has an immediate, negative impact on small jack pine budworms which are reliant on this resource (Nealis and Lomic 1994) but less so for spruce budworm and western spruce budworm which may still mine previous years' needles in the absence of pollen cones. Nonetheless, dispersal losses will increase. Eventually the negative feedback from damage will become more significant for these species as needles become sparse and needlemining more difficult, particularly for western spruce budworm (Nealis and Régnière 2009). It takes even longer for these negative feedbacks to affect spruce budworm where host foliage remains plentiful and palatable for several years and resource-related mortality does not become apparent until the vulnerable conifer component of the stand dies and becomes replaced by gaps and non-host species (Régnière and Nealis 2008). Thus delayed negative feedback from the host occurs in all species; it is just a question of how long it takes to become significant for population rates of change (Fig. 5).

Once bottom-up feedbacks change the resource environment, the rate of change in budworm densities becomes neutral and then negative (Nealis and Régnière 2004a). Population density decreases unless subsidised by immigration. Apparent, or relative, rates of parasitism increase even without a substantive increase in parasitoid 
Fig. 5. Trophic interactions and decline of budworm populations. As budworm populations ( $\left.\mathrm{R}_{\text {budworm }}\right)$ approach the capacity of the host resource $\left(\mathrm{K}_{\text {budworm }}\right)$, negative feedbacks result in greater variation and declining trend in population density. At the same time, natural enemy capacity ( $\left.K_{\text {natural enemies }}\right)$ increases relative to budworm densities creating a greater probability of population decline. Note the generation scale for development of this tri-trophic interaction varies by species although the absolute values are an approximation (modified from graphic by J. Régnière).

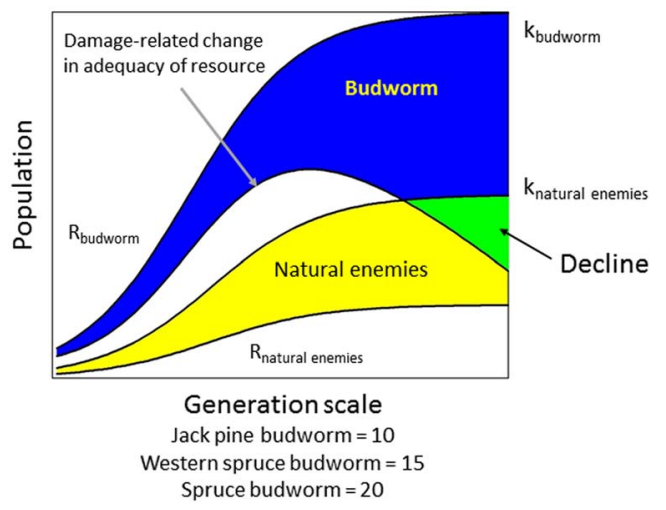

density simply because budworm densities are lower and parasitoid densities are not closely dependent on local budworm populations. So, the collapse of budworm populations initiated by negative, bottom-up feedbacks becomes more likely as the great diversity of predators, parasitoids, and diseases further depress survival and recruitment (Fig. 5). When these top-down losses do not occur, budworm outbreaks persist, causing significant tree mortality and driving the forest to a major episode of change (Ostaff and MacLean 1989; Nealis and Régnière 2004b). The frequency and extent of such severe events varies by species. In the jack pine budworm and western spruce budworm where the shift from a positive to a negative bottom-up feedback is relatively fast and direct, stand destruction is less common than death of smaller trees and thinned crowns with the exception of stands with a substantial Abies component (Wulf and Cates 1987). In spruce-fir forests, where bottom-up feedbacks are weakest and have a significant effect on budworm populations only in the extreme, significant damage to forests is more frequent, especially in balsam-fir dominated stands (MacLean 1980).

\section{Summary}

Trophic interactions are fundamental ecological relationships that integrate several small-scale biotic interactions such as top-down or bottomup perturbations and shed light on population patterns. To explore this for conifer-feeding budworms, factors that influence populations are stratified by trophic level and their interactions examined as populations proceed through different phases of change. This perspective gains further generality by comparing the ecology of closely related budworm species to identify shared phylogenetic constraints and adaptive syndromes that shape their common life history strategies. When these common life histories play out in different forest environments, emergent patterns reveal how ecological relationships translate the adaptations of individuals to population patterns in variable environments.

A defining phylogenetic constraint for Choristoneura budworms is their specialised feeding on current-year buds of a small group of related host plants. The constraint is temporal as fresh buds provide adequate nutrition only for a short period of time relative to the time required for larval feeding and maturation. The adaptive syndrome mitigating this constraint is that budworms overwinter as larvae and emerge early in the spring ready to feed immediately on the earliest available buds. This precocious emergence, however, comes with a cost as budworms typically emerge before current-year foliage is suitable and so must forage extensively for several days and even weeks until buds are available. The risk of dispersal associated with this foraging varies within and among species such that different survival patterns emerge. At the finest spatial scale, early-instar budworms expand the narrow seasonal window of plant adequacy by exploiting previous years' needles and pollen cones as temporary resources. The production of pollen cones itself is periodic and regionally synchronised in northern conifer species and so there are periods when this alternative resource is especially abundant over large areas. Budworm species feeding on true fir and, to some extent, spruce and Douglas-fir can also use previous years' foliage but old foliage of pines is unpalatable so jack pine budworm is more dependent on pollen cones to bridge the period between emergence and bud flush. As budworm 
damage increases, pollen cone production is reduced with immediate, dire consequences for jack pine budworm but less so for non-pine feeding budworms. The increasing negative, bottom-up feedbacks from feeding damage ultimately occurs in all budworm systems but at different temporal rates and spatial scales (Cooke et al. 2007). Whereas the bottom-up feedback affects survival at the branch and tree levels within a few years for jack pine budworm (Nealis and Lomic 1994) and a little longer in western spruce budworm (Nealis and Régnière 2009), it does not become significant for survival of spruce budworm until the change in resources occurs at the stand level (Régnière and Nealis 2008) (Figs. 3, 5).

Delayed, density-dependent feedbacks from bottom-up sources might be sufficient to explain the basic oscillation in budworm populations via changes in generation survival but more can be explained by including the interaction with top-down sources of mortality. Endemic budworm population levels can be determined, in part, by resource availability but also maintained by intense pressure from specialised natural enemies with strong functional responses. Budworm populations may be kept so low by natural enemies that local mating success is compromised, further impeding population increase (Régnière et al. 2012a). Improved suitability of forest condition for budworms as conifer stands develop postdisturbance has two components: (1) the relatively rapid increase in foliage, augmented by periodic pollen cone production and (2) the more gradual creation of tree-scale and stand-scale structure which acts to reduce losses of dispersing small larvae and perhaps buffers microclimates.

Under the conditions set by the resource, budworm populations will become sufficiently abundant to saturate the functional response of natural enemies so that the generation rate of survival favours continued increase in budworm density. Moth dispersal accelerates the inclusion of more and more stands in the outbreak so that the dynamics of any one stand becomes connected to that of the landscape, reducing the dominant influence of local conditions. Knowing the density and spatial scale at which the dynamics transition from local to areawide outbreak phases is a critical contemporary question in budworm population dynamics.

Periods of more rapid change in local budworm density are associated with major, relatively fast shifts in the nature and impacts of natural enemies; first the apparent disappearance of specialist natural enemy species as budworm populations increase beyond the endemic phase and again at the end of the outbreak when generalist natural enemies increase their impact as forest condition is degraded and negative feedbacks reduce local densities (Figs. 4, 5).

This review has focussed on trophic interactions and the characteristics of outbreak patterns in several related budworm species based on the past three decades of laboratory and stand-level studies where processes and population structure and density can be measured and experiments conducted. Population models produced during this same period were built entirely on evidence compiled during the 30 years previous to most of the studies reviewed here. Those models identified phases in the outbreak cycle where trophic interactions had characteristic and significant effects on population rates of change but lacked sufficient information to analyse these interactions over widely variable environments and timescales. For example, the changing interactions of bottom-up and top-down effects conditioned by budworm density and recruitment discussed here may create a boomand-bust system with multiple equilibria (Ludwig et al. 1978) but there is insufficient evidence that rates of change in population densities actually accelerate at these critical points. A unique conditional equilibrium that varies with the local state of trophic interactions would also generate richly complex dynamics (Royama 1992) and may be a more powerful, if less prescriptive, model of the system.

The influences of weather and dispersal have been mentioned only insofar as they modulate these trophic interactions. But these stochastic modulations can be significant: think of largescale immigration of moths to a susceptible forest or a sequence of weather patterns that promotes production of pollen cones or increases overwinter survival over a larger geographic area with susceptible hosts (Fig. 3). Certainly any future model must deal explicitly with moth dispersal as it obscures detection of alternative tri-trophic possibilities by accelerating rates of increase extrinsically; an irruptive process. Recent progress promises new insights from different perspectives (Régnière et al. 2012a; Sturtevant et al. 2015).

A new cycle of population models is surely due. Population models that include processes informed by the last generation of research will 
reduce the inherent uncertainty of the nonlinear effects of weather and dispersal of moths, which historically have been assumed, ignored, or dismissed. In turn, a greater understanding of weather and dispersal will shed light on how changes in climate and forest landscape will interact with our understanding of trophic relationships to produce the disturbance patterns that will continue to shape the future of northern forest ecosystems.

\section{Acknowledgements}

Tom Royama's critical approach to data and insistence on rigorous methods launched the latest generation of research with a clear goal and high standard of scientific conduct. Jacques Régnière has been my long-time research partner, challenging my half-baked ideas while always adding value. Barry Cooke has been a generous listening post and broadens my thinking with his insight. I am grateful to him and Brian Van Hezewijk for improving an earlier draft of this paper.

\section{References}

Albert, P.J. and Bauce, E. 1994. Feeding preferences of fourth- and sixth-instar spruce budworm (Lepidoptera: Tortricidae) larvae for foliage extracts from young and old balsam fir hosts. Environmental Entomology, 23: 645-653.

Alfaro, R.I., Berg, J., and Axelson, J. 2014. Periodicity of western spruce budworm in southern British Columbia, Canada. Forest Ecology and Management, 315: 72-79.

Alfaro, R.I., Taylor, S., Brown, R.G., and Clowater, J.S. 2001. Susceptibility of northern British Columbia forests to spruce budworm defoliation. Forest Ecology and Management, 145: 181-190.

Alfaro, R.I., Van Sickle, G.A., Thomson, A.J., and Wegwitz, E. 1982. Tree mortality and radial growth losses in a Douglas-fir stand in British Columbia. Canadian Journal of Forest Research, 12: 780-787.

Anderson, D.P. and Sturtevant, B.R. 2011. Pattern analysis of eastern spruce budworm Choristoneura fumiferana dispersal. Ecography, 34: 488-497.

Anderson, L., Carlson, C.E., and Wakimoto, R.H. 1987. Forest fire frequency and western spruce budworm outbreaks in western Montana. Forest Ecology and Management, 22: 251-260.

Arif, B.M., Guangyu, Z., and Jamieson, P. 1986. A comparison of three granulosis viruses isolated from Choristoneura spp. Journal of Invertebrate Pathology, 48: 180-186.

Baskerville, G.L. 1975. Spruce budworm: super silviculturist. Forestry Chronicle, 51: 138-140.
Bauce, E. and Han, E. 2001. Desiccation resistance in pre-diapause, diapause and post-diapause larvae of Choristoneura fumiferana (Lepidoptera: Tortricidae). Bulletin of Entomological Research, 91: 321-326.

Beckwith, R.C. and Burnell, D.G. 1982. Spring larval dispersal of the western spruce budworm (Lepidoptera: Tortricidae) in north-central Washington. Environmental Entomology, 11: 828-832.

Bennett, A.M.R. 2008. Review and identification keys to the ichneumonid parasitoids (Hymenoptera: Ichneumonidae) of Nearctic Choristoneura species (Lepidoptera: Tortricidae). The Canadian Entomologist, 140: 1-47.

Bergeron, Y., Leduc, A., Morin, H., and Joyal, C. 1995. Balsam fir mortality following the last spruce budworm outbreak in northwestern Quebec. Canadian Journal of Forest Research, 25: 1375-1384.

Blais, J.R. 1952. The relationship of the spruce budworm (Choristoneura fumiferana, Clem.) to the flowering condition of balsam fir (Abies balsamea (L.) Mill.). Canadian Journal of Zoology, 30: 1-29.

Blais, J.R. 1954. The recurrence of spruce budworm infestations in the past century in the Lac Seul area of northwestern Ontario. Ecology, 35: 62-71.

Blais, J.R. 1965a. Spruce budworm outbreaks in the past three centuries in the Laurentide Park, Quebec. Forest Science, 11: 130-138.

Blais, J.R. 1965b. Parasite studies in two residual spruce budworm (Choristoneura fumiferana (Clem.)) outbreaks in Quebec. The Canadian Entomologist, 97: 129-136.

Blais, J.R. 1968. Regional variation in susceptibility of eastern North American forests to budworm attack based on history of outbreaks. The Forestry Chronicle, 44: 17-23.

Blais, J.R. 1983. Trends in the frequency, extent, and severity of spruce budworm outbreaks in eastern Canada. Canadian Journal of Forest Research, 13: 539-547.

Blais, J.R. 1985. Epidemiology of the spruce budworm in western Ontario: a discussion. Forestry Chronicle, 61: 494-498.

Bouchard, M. and Auger, I. 2014. Influence of environmental factors and spatio-temporal covariates during the initial development of a spruce budworm outbreak. Landscape Ecology, 29: 111-126.

Bouchard, M., Kneeshaw, D., and Bergeron, Y. 2005. Mortality and stand renewal patterns following the last spruce budworm outbreak in mixed forests of western Quebec. Forest Ecology and Management, 204: 297-313.

Boulanger, Y. and Arseneault, D. 2004. Spruce budworm outbreaks in eastern Quebec over the last 450 years. Canadian Journal of Forest Research, 34: 1035-1043.

Boulanger, Y., Arseneault, D., Morin, H., Jardon, Y., Bertrand, P., and Dagneau, C. 2012. Dendrochronological reconstruction of spruce budworm (Choristoneura fumiferana) outbreaks in southern Quebec for the last 400 years. Canadian Journal of Forest Research, 42: 1264-1276. 
Burleigh, J.S., Alfaro, R.I., Borden, J.H., and Taylor, S. 2002. Historical and spatial characteristics of spruce budworm Choristoneura fumiferana (Clem.) (Lepidoptera: Tortricidae) outbreaks in northeastern British Columbia. Forest Ecology and Management, 168: 301-309.

Campbell, E.M., MacLean, D.A., and Bergeron, Y. 2008. The severity of budworm-caused growth reductions in balsam fir/spruce stands varies with the hardwood content of surrounding forest landscapes. Forest Science, 54: 195-205.

Campbell, R., Smith, D.J., and Arsenault, A. 2006. Multicentury history of western spruce budworm outbreaks in interior Douglas-fir forests near Kamloops, British Columbia. Canadian Journal of Forest Research, 36: 1758-1769.

Campbell, R.W. 1993. Population dynamics of the major North American needle-feeding budworms. Research Paper PNW-RP-463. United States Department of Agricutlure, Forest Service, Portland, Oregon, United States of America.

Campbell, R.W., Torgersen, T.R., and Srivastava, N. 1983. A suggested role for predaceous birds and ants in the population dynamics of the western spruce budworm. Forest Science, 29: 779-790.

Candau, J.-N. and Fleming, R.A. 2005. Landscapescale spatial distribution of spruce budworm defoliation in relation to bioclimatic conditions. Canadian Journal of Forest Research, 35: 2218-2232.

Candau, J.-N., Fleming, R.A., and Hopkin, A. 1998. Spatiotemporal patterns of large-scale defoliation caused by the spruce budworm in Ontario since 1941. Canadian Journal of Forest Research, 28: 1733-1741.

Clancy, K.M. 2002. Mechanisms of resistance in trees to defoliators. In Mechanisms and deployment of resistance in trees to insects. Edited by M.R. Wagner, K.M. Clancy, F. Lieutier, and T.D. Paine. Kluwer Academic Publishers, Dordrecht, The Netherlands. Pp. 77-101.

Clancy, K.M., Giese, R.L., and Benjamin, D.M. 1980. Predicting jack-pine budworm infestations in northwestern Wisconsin. Environmental Entomology, 9: 743-751.

Cooke, B.J., Nealis, V.G., and Régnière, J. 2007. Insect defoliators as periodic disturbances in northern forest ecosystems. In Plant disturbance ecology; the processes and the response. Edited by E.A. Johnson and K. Miyanishi. Academic Press, London, United Kingdom. Pp. 487-526.

Craighead, F.C. 1924. Studies on the spruce budworm [Cacoecia fumiferana Clem.]. Part II. General bionomics and possibilities for prevention and control. Canada Department of Agriculture Technical Bulletin, 37: 28-57.

Cunningham, J.C. and Kaupp, W.J. 1995. Insect viruses. In Forest insect pests in Canada. Edited by J.A. Armstrong and W.G.H. Ives. Natural Resources Canada, Science and Sustainable Development Directorate, Ottawa, Ontario, Canada. Pp. 327-340.
Dang, P.T. 1985. Key to adult males of conifer-feeding species of Choristoneura Lederer (Lepidoptera: Tortricidae) in Canada and Alaska. The Canadian Entomologist, 117: 1-5.

Delvas, N., Bauce, É., Labbé, C., Ollevier, T., and Bélanger, R. 2011. Phenolic compounds that confer resistance to spruce budworm. Entomologia Experimentalis et Applicata, 141: 35-44.

Dobesberger, E.J., Lim, K.P., and Raske, A.G. 1983. Spruce budworm (Lepidoptera: Tortricidae) moth flight from New Brunswick to Newfoundland. The Canadian Entomologist, 115: 1641-1645.

Dodds, K.A., Clancy, K.M., Leyva, K.J., Greenberg, D., and Price, P.W. 1996. Effects of Douglas-fir foliage age class on western spruce budworm oviposition choice and larval performance. Great Basin Naturalist, 56: 135-141.

Eveleigh, E.S., Lucarotti, C.J., McCarthy, P.C., and Morin, B. 2012. Prevalence, transmission and mortality associated with Nosema fumiferanae (Thomson) (Microsporidae) infections in field populations of spruce budworm Choristoneura fumiferana (Clem.). Agricultural and Forest Entomology, 14: 389-398. doi:10.1111/j.1461-9563. 2012.00580.x.

Eveleigh, E.S., McCann, K.S., McCarthy, P.C., Pollock, S.J., Lucarotti, C.J., Morin, B., et al. 2007. Fluctuations in density of an outbreak species drive diversity cascades in food webs. Proceedings of the National Academy of Sciences, 104: 16976-16981.

Farrar, J.L. 1995. Trees in Canada. Catalogue number Fo42-234/1995E, Canadian Forest Service, Ottawa, Ontario, Canada.

Fernández-Triana, J.L. and Huber, J.T. 2010. Braconid parasitoids (Hymenoptera: Braconidae) of Nearctic Choristoneura species (Lepidoptera: Tortricidae), with a summary of other parasitoid families attacking Choristoneura. The Canadian Entomologist, 142: 295-343.

Flower, A., Gavin, D.G., Heyerdahl, E.K., Parsons, R.A., and Cohn, G.M. 2014. Drought-triggered western spruce budworm outbreaks in the interior Pacific Northwest: a multi-century dendrochronological record. Forest Ecology and Management, 324: 16-27.

Fowler, G.W. and Simmons, G.A. 1987. Regression equations and table for estimating numbers of eggs in jack pine budworm (Lepidoptera: Tortricidae) egg masses in Michigan. Great Lakes Entomologist, 20: $157-160$.

Freeman, T.N. 1947. The external anatomy of the spruce budworm Choristoneura fumiferana (Clem.). (Lepidopteraa; Tortricidae). The Canadian Entomologist, 79: 21-31.

Freeman, T.N. 1967. On coniferophagous species of Choristoneura (Lepidoptera: Tortricidae) in North America I. Some new forms of Choristoneura allied to $C$. fumiferana.. The Canadian Entomologist, 99: 449-455. 
Graham, R.I., Morin, B., Lapointe, R., Nealis, V.G., and Lucarotti, C.J. 2008. Molecular characterisation of a cypovirus isolated from western spruce budworm, Choristoneura occidentalis. Archives of Virology, 153: 1759-1763.

Grant, G.G. 2006. Foliage architecture explains oviposition preference of spruce budworm (Lepidoptera: Tortricidae) for white spruce over balsam fir. The Canadian Entomologist, 138: 198-204.

Gray, D.R. 2008. The relationship between climate and outbreak characteristics of the spruce budworm in eastern Canada. Climatic Change, 87: 361-383.

Gray, D.R. 2013. The influence of forest composition and climate on outbreak characteristics of the spruce budworm in eastern Canada. Canadian Journal of Forest Research, 43: 1181-1195.

Gray, D.R., Régnière, J., and Boulet, B. 2000. Analysis and use of historical patterns of spruce budworm defoliation to forecast outbreak patterns in Quebec. Forest Ecology and Management, 127: 217-231.

Greenbank., D.O. 1956. The role of climate and dispersal in the initiation of outbreaks of the spruce budworm in New Brunswick. I. The role of climate. Canadian Journal of Zoology, 34: 453-476.

Greenbank, D.O. 1957. The role of climate and dispersal in the initiation of outbreaks of the spruce budworm in New Brunswick. II. The role of dispersal. Canadian Journal of Zoology, 35: 385-403.

Greenbank, D.O. 1963. Staminate flowers and the spruce budworm. In The dynamics of epidemic spruce budworm populations. Edited by R.F. Morris. Memoirs of the Entomological Society of Canada, 31: 202-218.

Greenbank, D.O., Schaefer, G.W., and Rainey, R.C. 1980. Spruce budworm (Lepidoptera: Tortricidae) moth flight and dispersal; new understanding from canopy observations, radar, and aircraft. Memoirs of the Entomological Society of Canada, 110: 1-49.

Gross, H.L. 1992. Impact analysis for a jack pine budworm infestation in Ontario. Canadian Journal of Forest Research, 22: 818-831.

Han, E.-N. and Bauce, E. 1998. Timing of diapause initiation, metabolic changes and overwintering survival of the spruce budworm, Choristoneura fumiferana. Ecological Entomology, 23: 160-167.

Harvey, G.T. 1967. On coniferophagous species of Choristoneura (Lepidoptera: Tortricidae) in North America. V. Second diapause as a species character. The Canadian Entomologist, 99: 486-503.

Harvey, G.T. 1985. The taxonomy of the coniferophagous Choristoneura (Lepidoptera: Tortricidae): a review. In Recent advances in spruce budworm research, Proceedings of the CANUSA Spruce Budworms Research Symposium, Bangor, Maine, September 16-20, 1984. Fo18-5/1984. Edited by C.J. Sanders, R.W. Stark, E.J. Mullins, and J. Murphy. Ministry of Supply and Services Canada, Ottawa, Ontario, Canada. Pp. 16-48.
Harvey, G.T. 1996. Genetic relationships among Choristoneura species (Lepidoptera: Tortricidae) in North America as revealed by isozyme studies. The Canadian Entomologist, 128: 245-262.

Harvey, G.T. 1997. Interspecific crosses and fertile hybrids among the coniferophagous Choristoneura (Lepidoptera: Tortricidae). The Canadian Entomologist, 129: 519-536.

Holling, C.S. 1988. Temperate forest insect outbreaks, tropical deforestation and migratory birds. Memoirs of the Entomological Society of Canada, 146: 21-32.

Holmes, S.B., Sanders, C.J., Fillman, D., and Welsh, D.A. 2009. Changes in forest bird community during an outbreak cycle of the spruce budworm in northwestern Ontario. Bird Populations, 9: 13-28.

Huber, J.T., Eveleigh, E., Pollock, S., and McCarthy, P. 1996. The chalcidoid parasitoids and hyperparasitoids (Hymenoptera: Chalcidoidea) of Choristoneura species (Lepidoptera: Tortricidae) in America north of Mexico. The Canadian Entomologist, 128: 1167-1220.

Hughes, J.S., Fortin, M.-J., Nealis, V., and Régnière, J. 2014. Pollen cone production in jack pine: spatial and temporal patterns subject to natural disturbance by the jack pine budworm. Canadian Journal of Forest Research, 44: 195-211.

Johnson, P.C. and Denton, R.E. 1975. Outbreaks of the western spruce budworm in the American northern Rocky Mountain area from 1922 through 1971. General Technical Report INT-20, United States Department of Agriculture, Forest Service, Ogden, Utah, United States of America.

Jones, D.D. 1979. The budworm site model. In Proceedings of a Conference on Pest Management, 25-29 October, 1976. Edited by G.A. Norton and C.S. Holling. International Institute for Applied Systems Analysis, Laxenburg, Austria. Pp. 91-155.

Kemp, W.P., Everson, D.O., and Wellington, W.G. 1985. Regional climatic patterns and western spruce budworm outbreaks. Technical Bulletin 1693, United States Department of Agriculture, Forest Service, Washington, District of Columbia, United States of America.

Kettela, E.G. 1983. A cartographic history of spruce budworm defoliation from 1967-1981 in eastern North America. Information Report DPC-X-14, Environment Canada, Fredericton, New Brunswick, Canada.

Krause, C. 1997. The use of dendrochronological material from buildings to get information about past spruce budworm outbreaks. Canadian Journal of Forest Research, 27: 69-75.

Lawrence, R.K., Mattson, W.J., and Haack, R.A. 1997. White spruce and the spruce budworm; defining the phenological window of susceptibility. The Canadian Entomologist, 129: 291-318.

Ludwig, D., Jones, D.D., and Holling, C.S. 1978. Qualitative analysis of insect outbreak systems: the spruce budworm and forest. Journal of Animal Ecology, 47: 315-332. 
Lumley, L.M. and Sperling, F.A.H. 2010. Integrating morphology and mitochondrial DNA for species delimitation wihin the spruce budworm (Choristoneura fumiferana) cryptic species complex (Lepidoptera: Tortricidae). Systematic Entomology, 35: 416-428.

Lumley, L.M. and Sperling, F.A.H. 2011. Utility of microsatellites and mitochondrial DNA for species delimitation in the spruce budworm (Choristoneura fumiferana) species complex (Lepidoptera: Tortricidae). Molecular Phylogenetics and Evolution, 58: 232-243.

Lysyk, T.J. 1989a. A multiple-cohort model for simulating jack pine budworm (Lepidoptera: Tortricidae) development under variable temperature conditions. The Canadian Entomologist, 121: 373-387.

Lysyk, T.J. 1989b. Stochastic model of eastern spruce budworm (Lepidoptera: Tortricidae) phenology on white spruce and balsam fir. Journal of Economic Entomology, 82: 1161-1168.

Lysyk, T.J. and Nealis, V.G. 1988. Temperature requirements for development of the jack pine budworm (Lepidoptera: Tortricidae) and two of its parasitoids (Hymenoptera). The Canadian Entomologist, 81: 1045-1051.

MacKay, M.R. 1962. Larvae of the North American Tortricinae (Lepidoptera: Tortricidae). The Canadian Entomologist Supplement, 28: 1-182.

Maclauchlan, L.E., Brooks, J.E., and Hodge, J.C. 2006. Analysis of historic western spruce budworm defoliation in south central British Columbia. Forest Ecology and Management, 226: 351-356.

MacLean, D.A. 1980. Vulnerablity of fir-spruce stands during uncontrolled spruce budworm outbreaks: a review and discussion. Forestry Chronicle, 56: 213-221.

MacLean, D.A. 1996. Forest management strategies to reduce spruce budworm damage in the Fundy Model Forest. Forestry Chronicle, 72: 399-405.

MacLean, D.A. and MacKinnon, W.E. 1997. Effects of stand and site characteristics on susceptibility and vulnerability of balsam fir and spruce to spruce budworm in New Brunswick. Canadian Journal of Forest Research, 27: 1859-1871.

Magnussen, S., Boudewyn, P., and Alfaro, A. 2004. Spatial prediction of the onset of spruce budworm defoliation. Forestry Chronicle, 80: 485-494.

Mathers, W.G. 1932. The spruce budworm in British Columbia. Forestry Chronicle, 8: 154-157.

Mattson, W.J., Haack, R.A., Lawrence, R.K., and Slocum, S.S. 1991. Considering the nutritional ecology of the spruce budworm in its management. Forest Ecology and Management, 39: 183-210.

Mattson, W.J., Knight, F.B., Allen, D.C., and Foltz, J.L. 1968. Vertebrate predation on the jack-pine budworm in Michigan. Journal of Economic Entomology, 61: 229-234.

McCullough, D.G. 2000. A review of factors affecting the population dynamics of jack pine budworm (Choristoneura pinus pinus Freeman). Population Ecology, 42: 243-256.
McGugan, B.M. 1954. Needle-mining habits and larval instars of the spruce budworm. The Canadian Entomologist, 86: 439-454.

McKnight, M.E. 1969. Distribution of hibernating larvae of the western spruce budworm, Choristoneura occidentalis, on Douglas-fir in Colorado. Journal of Economic Entomology, 62: 139-142.

Miller, C.A. 1958. The measurement of spruce budworm populations and mortality during the first and second larval instars. Canadian Journal of Zoology, 36: $409-423$.

Miller, C.A. 1963. Parasites and the spruce budworm. In The dynamics of epidemic spruce budworm populations. Edited by R.F. Morris. Memoirs of the Entomological Society of Canada, 31: $228-244$.

Miller, C.A. and Renault, T.R. 1976. Incidence of parasitoids attacking endemic spruce budworm (Lepidoptera: Tortricidae) populations in New Brunswick. The Canadian Entomologist, 108: 1045-1052.

Morin, H., Paprise, D., and Bergeron, Y. 1993. Chronology of spruce budworm outbreaks near Lake Duparquet, Abitibi region, Quebec. Canadian Journal of Forest Research, 23: 1497-1506.

Morris, R.F. 1963a. The dynamics of epidemic spruce budworm populations. Memoirs of the Entomological Society of Canada, 31: 1-332.

Morris, R.F. 1963b. The development of predictive equations for the spruce budworm based on key-factor analysis. In The dynamics of epidemic spruce budworm populations. Edited by R.F. Morris. Memoirs of the Entomological Society of Canada, 31: 116-129.

Morris, R.F. 1963c. Foliage depletion and the spruce budworm. In The dynamics of epidemic spruce budworm populations. Edited by R.F. Morris. Memoirs of the Entomological Society of Canada, 31: 223-228.

Morris, R.F., Cheshire, W.F., Miller, C.A., and Mott, D.G. 1958. The numerical response of avian and mammalian predators during a gradation of the spruce budworm. Ecology, 39: 487-494.

Nealis, V. 1987. The number of instars in jack pine budworm, Choristoneura pinus pinus Free. (Lepidoptera: Tortricidae), and the effect of parasitism on head capsule width and development time. The Canadian Entomologist, 119: 773-777.

Nealis, V.G. 1988. Weather and the ecology of Apanteles fumiferanae Vier. (Hymenoptera: Braconidae). In Paths from a viewpoint: the Wellington festschrift on insect ecology. Edited by T.S. Sahota and C.S. Holling. Memoirs of the Entomological Society of Canada, 146: 57-70.

Nealis, V.G. 1991. Parasitism in sustained and collapsing populations of the jack pine budworm, Choristoneura pinus pinus Free. (Lepidoptera: Tortricidae), in Ontario 1985-1987. The Canadian Entomologist, 123: $1065-1075$. 
Nealis, V.G. 1995. Population biology of the jack pine budworm. In Jack pine budworm biology and management. Edited by W.J.A. Volney, V.G. Nealis, G.M. Howse, A.R. Westwood, D.G. McCullough, and B.L. Laishley, Information Report NOR-X-342. Catalogue No. Fo46-12/342E, Minister of Supply and Services Canada, Ottawa, Ontario, Canada. Pp. 55-71.

Nealis, V.G. 2003. Host plant relationships and comparative ecology of conifer-feeding budworms (Choristoneura spp.). In Proceedings Ecology, Survey and Management of Forest Insects. General Technical Report NE-311. Edited by M.L. McManus and A.M. Liebhold. United States Department of Agriculture, Forest Service, Newtown Square, Pennsylvania, United States of America. Pp. 68-74.

Nealis, V.G. 2005. Diapause and voltinism in western and 2-year-cycle spruce budworms (Lepidoptera: Tortricidae) and their hybrid progeny. The Canadian Entomologist, 137: 584-597.

Nealis, V.G. 2012. The phenological window for western spruce budworm: seasonal decline in resource quality. Agricultural and Forest Entomology, 14: $340-347$.

Nealis, V.G. and Lomic, P.V. 1994. Host-plant influence on the population ecology of the jack pine budworm, Choristoneura pinus (Lepidoptera: Tortricidae). Ecological Entomology, 19: 367-373.

Nealis, V.G. and Lysyk, T.J. 1988. Sampling overwintering jack pine budworm, Choristoneura pinus pinus Free. (Lepidoptera: Tortricidae), and two of its parasitoids (Hymenoptera). The Canadian Entomologist, 120: 1101-1111.

Nealis, V.G., Magnussen, S., and Hopkin, A.A. 2003. A lagged, density-dependent relationship between jack pine budworm Choristoneura pinus pinus and its host tree Pinus banksiana. Ecological Entomology, 28: 183-192.

Nealis, V.G. and Nault, J.R. 2005. Seasonal changes in foliar terpenes indicate suitability of Douglas-fir buds for western spruce budworm. Journal of Chemical Ecology, 31: 683-696.

Nealis, V.G. and Régnière, J. 2004a. Fecundity and recruitment of eggs during outbreaks of the spruce budworm. The Canadian Entomologist, 136: 591-604.

Nealis, V.G. and Régnière, J. 2004b. Insect-host relationships influencing disturbance by the spruce budworm in a boreal mixedwood forest. Canadian Journal of Forest Research, 34: 1870-1882.

Nealis, V.G. and Régnière, J. 2009. Risk of dispersal in western spruce budworm. Agricultural and Forest Entomology, 11: 213-223.

Nealis, V.G. and Régnière, J. 2014. An individualbased phenology model for western spruce budworm (Lepidoptera: Tortricidae). The Canadian Entomologist, 146: 306-320.

Nealis, V.G., Turnquist, R., Morin, B., Graham, R.I., and Lucarotti, C.J. 2015. Baculoviruses in populations of western spruce budworm. Journal of Invertebrate Pathology, 127: 76-80.
O'Hara, J.E. 2005. A review of the tachinid parasitoids (Diptera: Tachinidae) of Nearctic Choristoneura species (Lepidoptera: Tortricidae), with keys to adults and puparia. Zootaxa, 938: 1-46.

Ostaff, D.P. and MacLean, D.A. 1989. Spruce budworm populations, defoliation, and changes in stand condition during an uncontrolled spruce budworm outbreak on Cape Breton Island, Nova Scotia. Canadian Journal of Forest Research, 19: 1077-1086.

Parfett, N., Clarke, D., and Van Sickle, A. 1994. Using a geographical information system for the input and analysis of historical western spruce budworm in British Columbia. FRDA Report 219, British Columbia Ministry of Forests, Victoria, British Columbia, Canada.

Perry, D.F. and Régnière, J. 1986. The role of fungal pathogens in spruce budworm population dynamics: frequency and temporal relationships. In Fundamental and applied aspects of invertebrate pathology. Edited by R.A. Samson, J.M. Vlak, and D. Peters. Foundation of the Fourth International Colloquium of Invertebrate Pathology, Wageningen, the Netherlands. Pp. 167-170.

Peterson, G., Allen, C.R., and Holling, C.S. 1998. Ecological resilience, biodiversity, and scale. Ecosystems, 1: 6-18.

Pilon, J.G. and Blais, J.R. 1961. Weather and outbreaks of the spruce budworm in the province of Quebec from 1939 to 1956. The Canadian Entomologist, 93: 118-123.

Price, P.W. 1994. Phylogenetic constraints, adaptive syndromes, and emergent properties: from individuals to population dynamics. Researches in Population Ecology, 36: 3-14.

Quayle, D., Régnière, J., Cappuccino, N., and Dupont, A. 2003. Forest composition, host-population density, and parasitism of spruce budworm Choristoneura fumiferana eggs by Trichogramma minutum. Entomologia Experimentalis et Applicata, 107: 215-227.

Régnière, J. 1984. Vertical transmission of diseases and population dynamics of insects with discrete generations: a model. Journal of Theoretical Biology, 107: 287-301.

Régnière, J. 1990. Diapause termination and changes in thermal responses during postdiapause development in larvae of the spruce budworm, Choristoneura fumiferana. Journal of Insect Physiology, 36: 727-735.

Régnière, J., Delisle, J., Pureswaran, D.S., and Trudel, R. 2012a. Mate-finding allee effect in spruce budworm population dynamics. Entomologia Experimentalis et Applicata, 146: 112-122.

Régnière, J. and Duval, P. 1998. Overwintering mortality of spruce budworm, Choristoneura fumiferana (Clem.) (Lepidoptera: Tortricidae), population under field conditions. The Canadian Entomologist, 130: 13-26. 
Régnière, J. and Fletcher, R.M. 1983. Direct measurement of spruce budworm (Lepidoptera: Tortricidae) larval dispersal in forest stands. Environmental Entomology, 12: 1532-1538.

Régnière, J. and Lysyk, T.J. 1995. Population dynamics of the spruce budworm, Choristoneura fumiferana. In Forest insect pests in Canada. Edited by J.A. Armstrong and W.G.H. Ives, Catalogue No. Fo24-235/1995E, Natural Resources Canada, Ottawa, Ontario, Canada. Pp. 95-105.

Régnière, J., Lysyk, T.J., and Auger, M. 1989. Population density estimation of spruce budworm, Choristoneura fumiferana (Clem.) (Lepidoptera: Tortricidae) on balsam fir and white spruce from 45-cm mid-crown branch tips. The Canadian Entomologist, 121: 267-281.

Régnière, J. and Nealis, V.G. 2007. Ecological mechanisms of population change during outbreaks of the spruce budworm. Ecological Entomology, 32: 461-477.

Régnière, J. and Nealis, V.G. 2008. The fine-scale population dynamics of spruce budworm: survival of early instars related to forest condition. Ecological Entomology, 33: 362-373.

Régnière, J., St-Amant, R., and Duval, P. 2012b. Predicting insect distributions under climate change from physiological responses: spruce budworm as an example. Biological Invasions, 14: 1571-1586.

Royama, T. 1984. Population dynamics of the spruce budworm Choristoneura fumiferana. Ecological Monographs, 54: 429-461.

Royama, T. 1992. Analytical population dynamics. Chapman and Hall, London, United Kingdom.

Royama, T. 2001. Measurement, analysis, and interpretation of mortality factors in insect survivorship studies, with reference to the spruce budworm, Choristoneura fumiferana (Clem.) (Lepidoptera: Tortricidae). Population Ecology, 43: 147-178.

Royama, T., MacKinnon, W.E., Kettela, E.G., Carter, N.E., and Hartling, L.K. 2005. Analysis of spruce budworm outbreak cycles in New Brunswick, Canada, since 1952. Ecology, 86: 1212-1224.

Ryerson, D.E., Swetnam, T.W., and Lynch, A.M. 2003. A tree-ring reconstruction of western spruce budworm outbreaks in the San Juan Mountains, Colorado, U.S.A. Canadian Journal of Forest Research, 33: 1010-1028.

Sanders, C.J. 1991. Biology of North American spruce budworms. In Tortricid pests, their biology, natural enemies and control. Edited by L.P.S. van der Geest and H.H. Evenhuis. Elsevier Science Publishers, Amsterdam, the Netherlands. Pp. 579-621.

Scarr, T.L., Ryall, K.L., and Hodge, P. 2012. Forest health conditions in Ontario, 2011. Ontario Ministry of Natural Resources, Toronto, Ontario, Canada.

Shepherd, R.F. 1959. Phytosociological and environmental characteristics of outbreak and non-outbreak areas of the two-year cycle spruce budworm, Choristoneura fumiferana. Ecology, 40: 608-620.
Shepherd, R.F. 1961. A comparison of the developmental rates of one- and two-year cycle spruce budworm. The Canadian Entomologist, 93: 764-771.

Shepherd, R.F. 1985. A theory on the effects of diverse host-climatic environments in British Columbia on the dynamics of western spruce budworm. In Recent advances in spruce budworm research, Proceedings of the CANUSA Spruce Budworms Research Symposium, Bangor, Maine, September 16-20, 1984. Fo18-5/1984. Edited by C.J. Sanders, R.W. Stark, E.J. Mullins, and J. Murphy. Ministry of Supply and Services Canada, Ottawa, Ontario, Canada. Pp. 60-70.

Shepherd, R.F. 1992. Relationships between attack rates and survival of western spruce budworm, Choristoneura occidentalis Freeman (Lepidoptera: Tortricidae), and bud development of Douglasfir, Pseudotsuga menziesii (Mirb.) Franco. The Canadian Entomologist, 124: 347-358.

Shepherd, R.F., Gray, T.G., and Harvey, G.T. 1995. Geographical distribution of Choristoneura species (Lepidoptera: Tortricidae) feeding on Abies, Picea, and Pseudotsuga in western Canada and Alaska. The Canadian Entomologist, 127: 813-830.

Shore, T.L. and Alfaro, R.I. 1986. The spruce budworm, Choristoneura fumiferana (Lepidoptera: Tortricidae), in British Columbia. Journal of the Entomological Society of British Columbia, 83: 31-38.

Silk, P.J. and Kuenen, L.P.S. 1988. Sex pheromones and behavioural biology of the coniferophagous Choristoneura. Annual Review of Entomology, 33: 83-101.

Simard, I., Morin, H., and Lavoie, C. 2006. A millennial-scale reconstruction of spruce budworm abundance in Saguenay, Québec, Canada. The Holocene, 16: 31-37.

Simpson, R. and Coy, D. 1999. An ecological atlas of forest insect defoliation in Canada 1980-1996. Information Report 206E, Natural Resources Canada, Fredericton, New Brunswick, Canada.

Sperling, F.A.H. and Hickey, D.A. 1995. Amplified mitochondrial DNA as a diagnostic marker for species of conifer-feeding Choristoneura (Lepidoptera: Tortricidae). The Canadian Entomologist, 127: 277-288.

Stehr, G. 1967. On coniferophagous species of Choristoneura (Lepidoptera: Tortricidae) in North America. II. Geographic distribution in accordance with forest regions. The Canadian Entomologist, 99: 456-463.

Sturtevant, B.R., Achtemeier, G.L., Charney, J.J., Anderson, D.P., Cooke, B.J., and Townsend, P.A. 2013. Long-distance dispersal of spruce budworm (Choristoneura fumiferana Clemens) in Minnesota (USA) and Ontario (Canada) via the atmospheric pathway. Agricultural and Forest Meteorology, 168: 186-200. 
Sturtevant, B.R., Cooke, B.J., MacLean, D.A., and Kneeshaw, D.D. 2015. Modeling insect disturbance across forested landscapes: insights from the spruce budworm. In Modeling Forest Landscape Disturbances. Edited by A. Perera, B.R. Sturtevant, and L. Buse. Springer, New York, New York, United States of America. In press.

Su, Q., MacLean, D.A., and Needham, T.D. 1996. The influence of hardwood content on balsam fir defoliation by spruce budworm. Canadian Journal of Forest Research, 26: 1620-1628.

Swetnam, T.W. and Lynch, A.M. 1989. A tree-ring reconstruction of western spruce budworm history in the southern Rocky Mountains. Forest Science, 35: 962-986.

Swetnam, T.W. and Lynch, A.M. 1993. Multicentury, regional-scale patterns of western spruce budworm outbreaks. Ecological Monographs, 63: 399-424.

Thomson, A.J. and Benton, R. 2007. A 90-year sea warming trend explains outbreak patterns of western spruce budworm on Vancouver Island. Forestry Chronicle, 83: 867-869.

Thomson, A.J., Shepherd, R.F., Harris, J.W.E., and Silversides, R.H. 1984. Relating weather to outbreaks of western spruce budworm, Choristoneura occidentalis (Lepidoptera: Tortricidae), in British Columbia. The Canadian Entomologist, 116: 375-381.

Thumbi, D.K., Béliveau, C., Cusson, M., Lapointe, R., and Lucarotti, C.J. 2013. Comparative genome sequence analysis of Choristoneura occidentalis, Freeman and C. rosaceana Harris (Lepidoptera: Tortricidae) alphabaculoviruses. Public Library of Science One, 8: 1-12. doi:10.1371/journal.pone.0068968.

Trier, T.M. and Mattson, W.J. 1997. Needle mining by the spruce budworm provides sustenance in the midst of privation. Oikos, 79: 241-246.

Turner, K.B. 1952. The relation of mortality of balsam fir, Abies balsamea (L.) Mill., caused by the spruce budworm, Choristoneura fumiferana (Clem.), to forest composition in the Algoma forest of Ontario. Canada Department of Agriculture Publication, 875: $1-107$.

van Frankenhuyzen, K., Ryall, K., Liu, Y., Meating, J., Bolan, P., and Scarr, T. 2011. Prevalence of Nosema sp. (Microsporidia: Nosematidae) during an outbreak of the jack pine budworm in Ontario. Journal of Invertebrate Pathology, 108: 201-208.

Van Sickle, G.A. 1987. Host responses. In Western spruce budworm. Technical Bulletin Number 1694. Edited by M.H. Brookes, R.W. Campbell, J.J. Colbert, R.G. Mitchell, and R.W. Stark. United States Department of Agricuture, Forest Service, Washington, District of Columbia, United States of America. Pp. 58-70.

Venier, L.A. and Holmes, S.B. 2010. A review of the interaction between forest birds and eastern spruce budworm. Canadian Journal of Forest Research, 18: 191-207.
Volney, W.J.A. 1988. Analysis of historic jack pine budworm outbreaks in the prairie provinces of Canada. Canadian Journal of Forest Research, 18: $1152-1158$.

Volney, W.J.A. 1989. Biology and dynamics of North American coniferophagous Choristoneura populations. Agricultural Reviews, 3: 133-156.

Volney, W.J.A. and Cerezke, H.F. 1992. The phenology of white spruce and the spruce budworm in northern Alberta. Canadian Journal of Forest Research, 22: 198-205.

Volney, W.J.A. and Fleming, R.A. 2007. Spruce budworm (Choristoneura spp.) biotype reactions to forest and climate characteristics. Global Change Biology, 13: 1630-1643.

Volney, W.J.A. and McCullough, D.G. 1994. Jack pine budworm population behaviour in northwestern Wisconsin. Canadian Journal of Forest Research, 24: 502-510.

Webb, F.W., Blais, J.R., and Nash, R.W. 1961. A cartographic history of spruce budworm outbreaks and aerial forest spraying in the Atlantic Region of North America, 1949-1959. The Canadian Entomologist, 93: 360-379.

Wellington, W.G., Fettes, J.J., Turner, K.B., and Belyea, R.M. 1950. Physical and biological indicators of the development of outbreaks of the spruce budworm, Choristoneura fumiferanae (Clem.) (Lepidoptera: Tortricidae). Canadian Journal of Research, D, 28: 308-331.

Wellington, W.G. and Henson, W.R. 1947. Notes on the effects of physical factors on the spruce budworm, Choristoneura fumiferana (Clem.). The Canadian Entomologist, 79: 168-170.

White, T.C.R. 1993. The inadequate environment. Nitrogen and the abundance of animals. SpringerVerlag, Berlin, Germany.

Wilson, G.G. 1987. Observations on the level of infection and intensity of Nosema fumiferanae (Microsporida) in two different field populations of the spruce budworm, Choristoneura fumiferana. Information Report FPM-X-79, Minister of Supply and Services, Ottawa, Ontario, Canada.

Wulf, N.W. and Cates, R.G. 1987. Site and stand characteristics. In Western spruce budworm. Technical Bulletin No. 1694. Edited by M.H. Brookes, R.W. Campbell, J.J. Colbert, R.G. Mitchell, and R.W. Stark. United States Department of Agriculture, Forest Service, Cooperative State Research Service, Washington, District of Columbia, United States of America. Pp. 89-115.

Zhang, Q.-B. and Alfaro, R.I. 2002. Periodicity of twoyear cycle spruce budworm outbreaks in central British Columbia: a dendro-ecological analysis. Forest Science, 48: 722-731.

Zhang, Q.-B. and Alfaro, R.I. 2003. Spatial synchrony of the two-year cycle budworm outbreaks in central British Columbia, Canada. Oikos, 102: 146-154. 